\title{
Performance and Techno-economic Analysis of a Hybrid Photovoltaic/thermal System for Building Application in Turkey
}

Kivanc Basaran ( $\square$ kivanc.basaran@cbu.edu.tr)

Manisa Celal Bayar University: Manisa Celal Bayar Universitesi https://orcid.org/0000-0001-9613-6620 İlayda Koç

Manisa Celal Bayar Üniversitesi: Manisa Celal Bayar Universitesi

\section{Research Article}

Keywords: Solar energy, performance analysis, PV/T collector, economic analysis, LCOE, NPV

Posted Date: February 13th, 2021

DOl: https://doi.org/10.21203/rs.3.rs-220189/v1

License: (c) (1) This work is licensed under a Creative Commons Attribution 4.0 International License.

Read Full License 


\title{
Performance and Techno-Economic Analysis of a Hybrid Photovoltaic/Thermal System for Building Application in Turkey
}

\author{
Kivanc Basaran ${ }^{1 *}$, İlayda Koç² \\ ${ }^{1}$ Manisa Celal Bayar University, Department of Energy Systems Engineering, Manisa, Turkey \\ ${ }^{2} \mathrm{~S} 2$ Automation Industry and Trade Inc. İzmir, Turkey \\ "kivanc.basaran@ cbu.edu.tr Phone number: +905325211871, Fax number: +902363142020
}

Abstract: Residential buildings need demand of energy for both heat and electricity. However, it's not always possible to meet this need by using individual panels due to the limited roof area. In addition, performing electrical and thermal energy production by using separate panels causes loss of performance and efficiency. The hybrid photovoltaic thermal (PV/T) collectors could be used in order to meet this necessity into the same collector. This paper investigates the performance and economic analysis of a PV/T collector for a building application in Turkey climatic conditions. For this purpose, the

18 Matlab/Simulink model of the PV/T collector was prepared. The electrical and thermal performance of the PV/T collector has 19 been investigated by changing various parameters on this model. In addition, market survey was conducted for economic 20 analysis. 11 different input variables such as average daily irradiation, electrical and thermal efficiency, price of electricity and 21 heating, operation and management cost, capital cost, debt to equity ratio, interest rate, discount rate and inflation rate are used to calculate the economic evaluation parameters such as net present value (NPV), levelized cost of energy (LCOE) and payback period (PBP). The results show that, the mean value of LCOE, NPV and PBP are $0.0467 € / \mathrm{kWh}, 7905.3 €$ and 6 years respectively for the project size at $8.96 \mathrm{~m} 2$ which is consist of 7 panels in the 25 years life cycle. Also, the average electrical and thermal efficiencies are defined as $13.4 \%$ and $69.3 \%$ respectively during.

\section{Introduction}

29 The sun is the largest energy source for the world. There are basically two ways to make available the energy provided by the sun. The first is to convert the solar energy into thermal energy and the other is to convert it into electrical energy. Because of

31 their unique advantages, both technologies are increasingly used in residential and industry applications. Because of the heat and electrical energy obtained from the sun often complement each other and in order to eliminate the disadvantages arising

33 from the use of these two technologies separately, it is thought that it is more convenient to produce heat and electrical energy 34 from the same panels. A PV/T collector is a module which combines the photovoltaic and thermal technologies into the same panel. 
36 The technical and economic suitability of a water based PV/T collectors was first stated by Martin Wolf in 1976. Then in 1978

37 the first liquid based PV/T was tested in a house by Böer and Tamm (2003). After these two experimental studies, many 38 researchers started to work in this field. In 1978, TRNSYST model was developed by using mathematical equations of active 39 cooled PV/T collectors at Arizona State University (Florschuetz 1979). In the study conducted in 1978 at the Massachusetts 40 Institute of Technology laboratories, the electrical and thermal efficiency of the PV/T collector was measured as $6.5 \%$ and $40 \%$ 41 respectively. After that, many studies have been done to increase the electrical and thermal efficiency of the PV/T collectors in 42 USA, Japan, Netherlands, Denmark and Germany (Cox and Raghuraman 1985; Suzuki and Kitamura 1979; Karl 1979; Komp 43 1985). Although studies on the PV/T collectors have been reduced due to low oil prices between 1980 and 1990, some studies 44 have been carried out in some European countries such as Switzerland and Yugoslavia (Schwartz et al. 1983; Lalovic et al. 45 1986; Lalovic et al. 1988). In 1992, with the political recognition of global warming and climate change, efforts in the PV/T 46 collectors have accelerated again. Especially in Germany, Denmark and the Netherlands, many projects were realized between 47 1990-2000 (Zondag et al. 2003; Leenders et al. 2000; Bakker et al. 2002; Bakker et al. 2004; Rockendorf et al. 1999; Hausler 48 and Rogass 2000; Soerensen 2001). In the following years, many countries such as Japan, India, Israel, Brazil, Taiwan, Cyprus 49 and the USA have been working in the field of PV/T (Tripanagnostopoulos et al. 2002; Tselepis and Tripanagnostopoulos 50 2002; Kalogirou 2001; Bergene and Løvvik 1995; Meir et al. 2002; Sandnes and Rekstad 2002; Hayakashi et al. 1989; 51 Fujisawa and Tani 1997; Ito et al. 1999; Huang et al. 1999; Huang et al. 2001; Garg and Agarwal 1995; Boer and Tamm 2003; 52 Thomas et al. 2000; Krauter et al. 1999; Krauter et al. 2001).

53 The water-based PV/T collectors, which are the subject of this study, are widely used since they have higher efficiency than 54 air-based collectors. Moreover, water-based collectors provide more uniform cooling of the PV cell than air-based collectors 55 (Jai 1994). Water based PV/T collectors can be manufactured in two ways such as glazed and unglazed. Due to the increase in 56 heat, the electrical efficiency of the glazed PV/T collector is low while the thermal efficiency of the unglazed PV/T collector is 57 low (Jin-Hee 2012). The electrical and thermal efficiency of the PV/T collectors depends on the flow distribution of the water 58 in the collector. Therefore, the design of water-carrying channels is of great importance. The channels should be optimized to 59 provide maximum heat transfer area and higher retention period for effective heat transfer from the collector to fluid. Aste et al. 60 (2015) were developed a PV/T collector that combines a top layer having amorphous silicon solar cells and microcrystalline 61 silicon, where the top cells absorb visible solar spectrum and convert it to electrical energy, while the bottom layer is sensitive 62 to near infrared region of solar radiation spectrum and converts it to thermal energy. Ji et al. (2006) were investigated effects of 63 the packing factor and flow rate on the overall efficiency of the PV/T. The results of that study showed that the increase of 64 packing factor drops the system thermal efficiency. 
65 The ambient and the collector temperature affect the electrical and the thermal efficiency of the PV/T. The temperature 66 increase in PV panels has a negative effect on the efficiency. Since the panel temperature absorbed by the liquid fluid in PV/T 67 collector, higher efficiency is obtained than similar PV panels. In (Saitoh et al. 2003), the authors analyzed the electrical and 68 thermal efficiency of water-based PV/T system experimentally. The results showed that the electrical efficiency varied from 10\% 69 to $13 \%$, and the thermal efficiency ranged from 40\% to 50\%. Minglu et al. (2016) was proposed a PV/T integrated dual-source 70 heat pump water heating system for Shanghai climate condition. They found that when the top temperature was $69.2{ }^{\circ} \mathrm{C}$, the 71 electrical conversion efficiency was $12.18 \%$ and when the operating temperature decrease to $45^{\circ} \mathrm{C}$ the electrical efficiency 72 increases to $13.4 \%$. Another experimental study was carried out at Politecnico di Milano University. The experimental 73 calibration and validation of the model was performed in outdoor conditions on a commercial PV/T product and the model was 74 run supposing the application in three different locations. In that study, the electrical efficiency of water-based PV/T was found 75 as $13 \%, 13.6 \%, 13.4 \%$ and the overall efficiency was found as $32.7 \%, 36.1$ and 40.6 for Paris, Milan, Athens respectively (] 76 Niccolò et al. 2016). Fudholi et al (2014) used the spiral flow absorber in order to increase the efficiency. Their results were 77 showed that the absorber produced a PVT efficiency of $68.4 \%$, a PV efficiency of $13.8 \%$, and a thermal efficiency of $54.6 \%$. 78 The other study has indicated that the building integrated PV/T collector's thermal energy efficiency of about 55-62\% and the 79 maximum achieved electrical efficiency was $11.4 \%$ (Ibrahim et al. 2014). Kiran and Devadiga (2014) reported that the 80 electrical efficiency of PV/T was $7.58 \%$ without cooling and $8.16 \%$ with cooling and the overall efficiency was $58.97 \%$. The 81 other experimental study was conducted during the spring season in United Arab Emirates. The results showed that electrical 82 efficiency increased from $15 \%$ to $20 \%$ and the thermal efficiency was found as $\% 60$ (Alzaabi et al. 2014). Rosa-Clot et al. 83 (2016) performed the efficiency analysis of PV and PV/T in Italy. They found the electrical efficiency of PV and PV/T as 8.77\% 84 and $13.19 \%$, respectively. Also, they found thermal efficiency of PV/T as $62 \%$. In addition to experimental studies, simulation studies were conducted in the literature for PV/T. The results obtained in these studies differ according to the results of experimental studies. Because, many factors which are affect the efficiency can be easily changed as desired. For example, in 87 the simulation study by Yazdanifard et al (2016), several parameters changed such as solar radiation, the number of pipes, 88 Reynolds number, packing factor, pipes diameter, and collector length to investigate the glass covered flat plate PV/T system's 89 electrical and thermal efficiency. They found maximum electrical and thermal efficiency as $17 \%$ and $70 \%$ respectively. 90 Daghigh et al. (2011) conducted the simulation study for amorphous silicon and crystalline silicon water based PV/T systems 91 in Malaysia. The results showed that the electrical and thermal efficiency of amorphous silicon PV/T was $4.9 \%$ and $72 \%$, 92 respectively and the electrical and thermal efficiency of crystalline silicon PV/T was $11.6 \%$ and $51 \%$ respectively. In the 93 literature, there are many studies examining the performance of PV/T collectors. As summarized above, the results obtained in 94 these studies are quite different from each other. The reasons for this are that the studies were carried out at different ambient 
95 temperatures in different regions, different cooling water flow rates and it is due to overestimation of the input parameters in 96 some simulation studies.

97 It has been seen in the detailed literature review that although there are many studies about PV/T collector performance 98 analysis which are evaluated electrical and thermal efficiency using different design parameters, there are also some economic 99 analysis studies. Different metrics can be used for the economic analysis such as payback period (PBP) (Herrando et al. 2014), 100 net present value (NPV) (Buker et al. 2014), levelized cost of energy (LCOE) (Riggs et al. 2017), energy payback time (EPBT) 101 (Wilson and Young 1996), Return on investment (ROI) (Zhang et al. 2015), internal rate of return (IRR) (Zhang et al. 2015), 102 benefit to cost ratio (BCR) and unit cost of energy (UCE) (Michael and Selvarasan 2017). TRNSYS model created for analysis 103 LCOE of domestic PV/T system which is based on amorphous silicon cells and crystalline silicon cells. In the study, monthly 104 meteorological data which are in TRNSYS program is used and annual performance degradation of PV panels was not taken 105 into consideration. The LCOE was found as $0.42 \mathrm{USD} / \mathrm{kWh}$ in ref (Coventry and Lovegrove 2003). The performance and 106 economic analysis of water cooled PV/T system and standard PV system were studied by Tripanagnostopoulos et al (2005).

107 They did not consider tax rebate or other cost reduction in order to find out the maximum time to overcome the initial cost and 108 maintenance cost in their economic analysis. They found estimated cost payback period for electricity saving and electricity 109 and gas saving between 10.3-28.2 year and 17.2-30.8 year according to the different temperature and tilt angel. In ref 110 (Kalogirou and Tripanagnostopoulos 2007), $300 \mathrm{~m}^{2}$ of hybrid PV/T collectors with polycrystalline and amorphous types PV 111 cell and a $10 \mathrm{~m}^{3}$ water storage tank was evaluated for Cyprus, Greece and Wisconsin. In the study, Typical Meteorological 112 Year (TMY) data is used in TRNSYS program. TMY was defined as a year, which was including all the meteorological data a 113 period the mean life of the system. The results show that the electrical production of polycrystalline PV/T is more than the 114 amorphous PV/T but the solar thermal fraction is slightly lower. Also, payback period was calculated for Cyprus, Greece and 115 Wisconsin as 26, 26, 28 years respectively. The water cooled PV/T collector which has different PV cell such as c-Si, p-Si, a$116 \mathrm{Si}$ (thin film), CdTe and CIGS evaluated and compared under New Delhi, India conditions. It was observer that the c-Si PV 117 cell produced maximum electricity energy, maximum annual overall thermal energy and exergy. Also, the results showed that 118 the maximum and minimum EPBT of 1.01 and 0.66 years on energy basis is obtained for c-Si and CIGS respectively, whereas 119 on exergy basis maximum EPBT of 5.72 years is obtained for a-Si and minimum of 3.44 in obtained for CIGS PV module 120 (Mishra and Tiwari 2013). Another economic analysis of water-cooled PV/T was carried out in UK. The authors introduced 121 that the annual energy savings was 10.3 MW and the NPV was calculated as 19456.14 Dollar for the 25-year life span of and 122 the cost of power generation was 0.0778 per kWh (Mahmut et al. 2014). Another water-cooled PV/T economic analysis study 123 conducted in a real office scale building to support its electricity and hot water demand via computer program simulations in 124 Hong Kong. The discounted payback period was estimated to be 14.7 years in that study (Ka-Kui et al. 2016). Herrando and 125 Markides (2016) studied on water cooled PV/T systems for distributed electricity and hot-water provision in a typical house in 
126 London, UK. According to the results of the study, a higher coverage of total household energy demands, and higher $\mathrm{CO}_{2}$

127 emission savings can be achieved if the system is installed under low solar irradiance levels and low ambient temperatures.

128 Also, they introduced that an annual electricity generation of $2.3 \mathrm{MWh}$, or a $51 \%$ coverage of the household's electrical

129 demand (compared to an equivalent PV-only value of 49\%), plus a significant annual water heating potential of to 1.0MWh, or

130 a 36\% coverage of the hot-water demand. The techno-economic challenges of PV/T systems in the housing sector for different

131 Europe locations, with local weather profiles and energy demand data relating to homes with a total floor area of $100 \mathrm{~m}^{2}$ were

132 studied by Alba et al (2017). In the study, TRNSYS simulation models were prepared for 4 different systems based on meeting

133 electricity and thermal energy demand and the economic viability of the solutions is then assessed based on their LCOE. The

134 results showed that the overall levelized cost of energy of these systems is found to be in the range of $0.06-0.12 € / \mathrm{kW} \mathrm{h}$, which

135 is $30-40 \%$ lower than that of equivalent PV-only systems. Augusto et al (2017) studied thermal and electric yearly energy

136 production of the PV/T, separate PV and solar thermal collector plants based on one-year measured data set in Italy. They

137 reported that $\mathrm{PV} / \mathrm{T}$ is economical solution compared to the $\mathrm{PV}$ and solar thermal collectors in order to produce electricity and

138 thermal energy. This experimental study has shown that the PV/T solar system can produce about $1362 \mathrm{kWh} /$ year of electricity

139 for $\mathrm{kWp}$ installed, while yearly heat generation may vary between 443 and $267 \mathrm{kWh} / \mathrm{m}^{2}$ depending on the mean inlet

140 temperature of the cooling fluid. The LCOE of the separate PV and solar thermal collector was computed at different cooling

141 water inlet temperatures, resulting in $0.082 \mathrm{Euro} / \mathrm{kWh}$ and $0.087 \mathrm{Euro} / \mathrm{kWh}$ and $0.092 \mathrm{Euro} / \mathrm{kWh}$ at, respectively, $35^{\circ} \mathrm{C}, 40^{\circ} \mathrm{C}$

142 and $45^{\circ} \mathrm{C}$ of cooling water inlet temperatures. In this study, measured meteorological data were used. But no information was

143 provided for annual produced energy degradation of PV/T collectors.

$144 \quad$ 1.1. Limitations of previous studies

145 It has been seen from detailed literature review that there are still limitation or gap on the economic analysis of the PV/T 146 systems. These can be summarized as follows.

147 - The amount of energy to be produced from the PV/T collector is calculated using monthly meteorological data.

148 Moreover, these data are often obtained from various simulation programs rather than being measured. However, performance 149 and economic analysis studies using monthly average data do not give clear technical and economic results.

150 - Many studies ignore the annual performance degradation for electricity and thermal production of the PV/T. Hence,

151 the annual generated energy amount doesn't change over the lifecycle of the system.

152 - The required electricity energy to circulate the water and the resulting loss of earnings wasn't considered in the 153 economic analysis.

154 - In many studies, an economic analysis was performed based on only the panel. There are no economic analysis 155 studies for the entire PV/T system. 
as interest rate, inflation rate and discounted rate. Also, the NPV value required to make an investment decision is often not calculated. PV/T systems are becoming feasible due to changing investment and financial costs. However, especially in recent years only a few economic studies have been listed for the PV/T systems

- In some countries there is no heating price. That is, as the heat energy is not purchased from the grid, such as electrical energy, the price is not specified. Therefore, heating prices should be determined correctly for the study region for the economic analysis of the PV/T systems. None of the articles has stated how the heat price is determined.

- In almost all studies, the electrical and thermal efficiency of the PV/T collector was taken constant while conducting economic analysis. Whereas electrical and thermal efficiency varies depending on many factors.

- Also including comprehensive energy and economic comparisons among optimized solutions as a function the design and operating parameters, weather conditions, and national energy prices.

\subsection{Aim and Novelty of This Work}

The main goal of this paper is to analyze the thermal-electrical performance of a PV/T collector and to assess the economic feasibility of water-based PV/T systems under real measured meteorological data. For this purpose, the meteorological data such as irradiation and temperature were collected every 5 minutes for one year. The thermal and the electrical performance analysis were performed using this real data for everyone hour. The economic analysis was performed by considering all financial and technical parameters such as annual degradation rate, inflation rate, dept to equity ratio, interest rate based on the yearly energy output. Therefore, this study will provide a critical view on design and the associated parameters that affect the $\mathrm{PV} / \mathrm{T}$ system performance and economic results.

The novelty of this study is that the entire gap in the literature listed above has been examined separately. These are summarized as follows.

- Hourly performance and energy production were performed for one year using real meteorological data. Then the annual performance degradation rate implemented for life cycle of the PV/T collector.

- While calculating the efficiency of the PV/T collectors, the ambient temperature as well as the main water temperature was taken into consideration and the heat and electrical energy to be produced were calculated by taking the efficiency values calculated on an hourly basis.

- $\quad$ The economic analysis was carried out using NPV, LCOE and PBP techniques which are most commonly used in the literature taken in to account all the technical and economical parameters. We present these techniques which examines the technical, financial, and geographic factors which affect the cost of heat and electrical production for the PV/T system.

The losses and the annual degradation of the entire system are included in the calculation. 
Hot water supply cost has been determined using the average unit price of some of the central hot water plants in

187 Turkey and it has been determined by considering the costs that will occur in case of using natural gas for heating.

188 The paper is organized as follows: Firstly, a detailed literature review was conducted, and related papers were presented in the 189 introduction in accordance with the subject compliance and the date of presentation. The remaining parts of the paper are 190 organized in the following order. Section 2 gives a detailed description of the PV/T system such as location, data set, PV/T 191 collector, measurement sensors and reference house. In section 3, the market price of the system equipments, electricity and 192 thermal energy prices, financial parameters and assumptions were explained. The electrical and thermal model, the economic 193 analysis model and the developed MATLAB/Simulink model of the PV/T collector were explained in section 4 . The rest of the 194 manuscript includes the results and conclusion sections.

\section{2. Description Of The PV/T System, Location, Data Set, Components And Reference House}

196 The PV/T systems are systems that produce electrical and low-grade thermal energy from solar irradiation simultaneously. 197 Therefore, PV/T systems require less space than PV and solar thermal systems. In addition to the advantage of these systems producing electricity and thermal energy at the same time, the cooling of the PV cell while the thermal energy is obtained has a

199 positive effect on the PV efficiency. The water is the most widely used fluid in PV/T systems due to its low price, availability 200 and cooling properties. The water-carrying pipes under the PV/T collector are intended to draw heat from the PV panel, 201 thereby improving the output voltage and current of the PV panel. At the same time, this heat is used for heating domestic water. In this study, the PV/T system consists of the 7 panels, converter, inverter, solar absorbing tube, storage tank and circulating pump. Figure 1 shows the block diagram of the analyzed system.

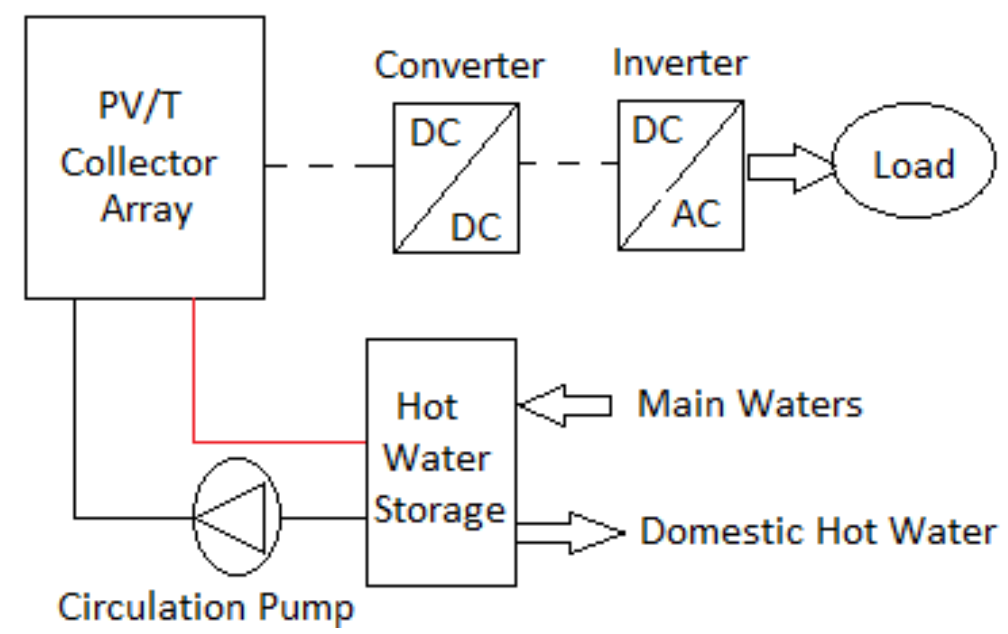

Fig. 1. Block Diagram of the PV/T System 


\subsection{Location of the PV/T System}

209 Aksaray was selected for the evaluation of the proposed PV/T system. Aksaray is located at a longitude of between $33-35^{\circ} \mathrm{E}$, 210 latitude of between $37-38^{\circ} \mathrm{N}$ and at an altitude of $980 \mathrm{~m}$. The yearly average solar irradiation is $1.603 \mathrm{kWh} / \mathrm{m}^{2}$, with a yearly 211 total irradiation period of over $2880 \mathrm{~h}$ and the average yearly annual temperature is $10^{\circ} \mathrm{C}$ in Aksaray.

212 The data were collected every 5 minutes from May 2016 to June 2018. This study was carried out using data which were 213 collected in the year 2017. The access rate to the data is greater than $99 \%$ during the year 2017 . The lost data occurs either due 214 to electrical maintenance outage or inverter communication module failure. The data was stored in a data logger. The data

215 logger records all data such as irradiation and temperature every 5 minute. The specifications of the data logger are given in 216 Table 1.

Table 1. Specification of Data Logger

\begin{tabular}{ll}
\hline Parameter & Value \\
\hline Power supply & $20-60 \mathrm{~V} \mathrm{DC}$ \\
Power consumption & Typically, $5 \mathrm{~W}$ \\
ESD protection & Tested in accordance with \\
& DIN EN $61000-4-2$ \\
Operating temperature & $-20{ }^{\circ} \mathrm{C}$ to $70{ }^{\circ} \mathrm{C}$ \\
Storage and transport temperature & $-20{ }^{\circ} \mathrm{C}$ to $85{ }^{\circ} \mathrm{C}$ \\
Protection class & IP 20 \\
Elevation & $\max .2000 \mathrm{~m}$ \\
Rel. air humidity & $\max .80 \%$ \\
Precision (Voltage input) & $0-10 \mathrm{~V} \mathrm{DC}, 2 \mathrm{mV} \mathrm{DC}$ \\
& $0-1 \mathrm{~V} \mathrm{DC}, 0,5 \mathrm{mV} \mathrm{DC}$ \\
& $0-100 \mathrm{mV} \mathrm{DC}, 50 \mu \mathrm{VC}$ \\
Precision (Current input) & $0-20 \mathrm{~mA}, 4 \mu \mathrm{A}$ \\
\hline
\end{tabular}

The global horizontal irradiance (GHI) and Plane-of-array (POA) irradiance, was measured by a Kipp\&Zonen SMP11 pyranometer. Typical measurement uncertainties of this device are shown in Table 2.

Table 2. Typical measurement uncertainties of irradiance sensors

\begin{tabular}{ll}
\hline Parameter & Kipp\&Zonen SMP 11 \\
\hline Response Time & $<2 \mathrm{~s}$ \\
Offset & $<2 \mathrm{~W} / \mathrm{m}^{2}$ \\
Temperature Dependency & $<1 \%$ \\
Non-stability & $<\mathbf{0 . 5 \%}$ \\
Non-linearity & $<0.2 \%$ \\
\hline
\end{tabular}

PT1000 temperature sensor with integrated converter was used to measure the ambient air temperature. With this sensor, the temperature between -50 and $70^{\circ} \mathrm{C}$ is converted into voltage values between $0 \mathrm{~V}$ and $10 \mathrm{~V}$. PT1000 temperature sensor (resistance) was used to measure module temperature connected directly to the back-sheet panel.

Since all data measured from the plant are recorded at intervals of 5 minutes for 24 hours, the data must be passed through quality control and filtered. The night measurements for irradiation were filtered due to the negative irradiance value. In addition, the results of irradiation measurements at sunrise or sunset may contain abnormal values. Also, the values of irradiation at sunrise and sunset are quite small and not effective for energy production. Apart from these, same measured 
230 values exceed their physical limits. So, a quality control procedure was applied, and some improper values were removed

231 from row data set. It has been lost values in some time periods during the year. Instead of these missing data, new values were

232 written according to the previous and next measured values. When measurements were taken at 5-minute intervals, new data

233 were close to the actual values. The number of raw data before the filtering process was 105120. After the filter process, the

234 data set contains 43800 values (Jacovides et al. 2016; Scharmer and Greif 2000; Reindl et al. 1990).

\section{$235 \quad 2.2 \quad$ Specification of PV/T Collector}

$236 \mathrm{PV} / \mathrm{T}$ collector is provided electricity and usable thermal hot water at the same time from one collector. In this study, water-

237 based PV/T collector has been selected. In this collector there are 72 PV cell with glass covered and 66 tubes. The gross area of

238 this collector is $1.28 \mathrm{~m}^{2}$. The maximum temperature and maximum operating pressure are $101^{\circ} \mathrm{C}$ and 6 bar respectively. The 239 specifications of the PV/T collector are given in Table 3.

Table 3. Specification of Proposed PV/T Collector

\begin{tabular}{|c|c|c|c|}
\hline Parameter & Symbol & Value & Unit \\
\hline Number of covers & $N_{g}$ & 1 & \\
\hline Ambient Temperature & $T_{a}^{\circ}$ & 293 & $\mathrm{~K}$ \\
\hline Emittance of plate & $\varepsilon_{p}$ & 0.95 & \\
\hline Emittance of cover & $\varepsilon_{e}$ & 0.88 & \\
\hline Number of tubes & $n_{t}$ & 66 & \\
\hline Number of cells & $n_{c}$ & 72 & \\
\hline System flow rate & $m$ & 2 & Lps \\
\hline Collector area & $A$ & 1.28 & $\mathrm{~m}^{2}$ \\
\hline Wind speed & $v$ & 2 & $\mathrm{~m} / \mathrm{s}$ \\
\hline PV Trans/Abs & $\tau \alpha_{p v}$ & 0.8 & \\
\hline Thermal Trans/Abs & $\tau \alpha_{T}$ & 0.925 & \\
\hline Absorber thickness & $t$ & 0.5 & $\mathrm{~mm}$ \\
\hline PV thickness & $L_{p v}$ & 0.4 & $\mathrm{~mm}$ \\
\hline PV conductivity & $k_{p v}$ & 130 & $\mathrm{~W} / \mathrm{mK}$ \\
\hline Tube Hydraulic Diameters & $d_{h}$ & 9.7 & $\mathrm{~mm}$ \\
\hline Tube spacing & $w$ & 0.1 & $\mathrm{~mm}$ \\
\hline Ratio of tube width to spacing & $d / w$ & 1.5 & \\
\hline Heat transfer coefficient & $h_{p v A}$ & 45 & $\mathrm{~W} / \mathrm{m}^{2} \mathrm{~K}$ \\
\hline Insulation conductivity & $k$ & 0.095 & $\mathrm{~W} / \mathrm{mK}$ \\
\hline Edge insulation thickness & $L_{\text {edge }}$ & 0.025 & $\mathrm{~m}$ \\
\hline Absorber conductivity & $k_{a b s}$ & 50 & $\mathrm{~W} / \mathrm{mK}$ \\
\hline Heat removal efficiency factor & $F_{R}$ & 0.85 & \\
\hline Packing Factor & $s$ & 0.4 & \\
\hline Collector heat losses coefficient & $U_{\text {loss }}$ & 6 & $\mathrm{~W} / \mathrm{mK}$ \\
\hline Tilt Angle & $\beta$ & 30 & degree \\
\hline Nominal Electrical Power & $P$ & 200 & $\mathrm{~W}$ \\
\hline Current at maximum power & Im & 5.28 & A \\
\hline Short circuit current & $I s c$ & 5.66 & A \\
\hline Voltage at Maximum power & $V m$ & 37.89 & $\mathrm{~V}$ \\
\hline Open Circuit voltage & Voc & 45.26 & $\mathrm{~V}$ \\
\hline Electrical efficiency & $\eta_{e}$ & 13.5 & $\%$ \\
\hline Thermal efficiency & $\eta_{\text {termal }}$ & 64.5 & $\%$ \\
\hline Temp. coeff. of $P m p p$ & Pmpp & -0.45 & $\% /{ }^{\circ} \mathrm{C}$ \\
\hline Temp. coeff. of $V o c$ & Voc & -0.34 & $\% /{ }^{\circ} \mathrm{C}$ \\
\hline Temp. coeff. of Isc & $I s c$ & +0.06 & $\% /{ }^{\circ} \mathrm{C}$ \\
\hline
\end{tabular}




\subsection{Reference House}

In this study, Simple House SFH15, which is used by IEA in Task44 project, was chosen as the reference for the analysis of the PV/T system (Heimrath and Haller 2007). The floor area of this house is $140 \mathrm{~m}^{2}$. The roof area on the south and north side is $59.7 \mathrm{~m}^{2}, 28.9 \mathrm{~m}^{2}$ respectively. The roof pitch of the southern facade is $20^{\circ}$ and the roof pitch of the north facade is $45^{\circ}$. It was assumed that 4 people lived in this house. The average collector area of considered collector is $1.37 \mathrm{~m}^{2}$ for one panel. Therefore, it was thought that the panels would be placed only on the southern façade. The average daily water consumption is 111 litres per capita in Turkey according to 2014 data of State Planning Organization. 40\% of clean domestic water is consumed as hot water. According to this statistic, hot water consumption of a standard 4-person house was accepted as $50 \mathrm{~L}$ per month.

The electricity demand of an individual house is dependent on the number of person and their activities, as well as on the electrical appliances available and their associated use. In this study, electricity consumption of a standard 4-person house was accepted as $200 \mathrm{kWh}$ per month.

\section{Market Analysis and Assumptions}

258 Turkey is one of the world's fastest growing energy markets in the world. Installed photovoltaic capacity has increased from 1,500 MW in 2017 to 5,238 MW in 2019. The cost of solar power has come down in recent years, majorly due to initiatives taken on an international level by governments and private organizations to promote research and development in this field. This cost reduction has made solar technology, especially solar PV technology, more accessible. Furthermore, favorable government regulations and private partnerships, downstream innovation and expansion, and various incentive schemes for the use of renewable energy for power generation, are also driving the solar power market at an exponential rate. The solar thermal system market was initiated during the 1970s in response to the growth of the tourism industry and the need for plentiful hot water. Turkey is one of the countries with the largest installed power in the world in this field. It is estimated that over 10 million $\mathrm{m}^{2}$ of flat plate collectors have been installed. Turkey offers opportunities in PV/T area because of the high potential of solar energy and experience in solar technology. The fact that PV/T systems have less installation costs than installing both individual PV and solar thermal collectors is considered an opportunity for the development of the PV/T market. In addition, because the PV market is directed to grid-connected distributed systems and national policies are developed for low-energy buildings, it is expected that the PV/T market will expand mostly in building sector in Turkey.

The unit electricity prices in Turkey are determined by Energy Market Regulatory Authority (EPDK). The unit price of electricity was determined as $0.5727 \mathrm{TL} / \mathrm{kWh}(0.096 \$ / \mathrm{kWh})$ for Single Term Residential Subscribers in December 2019. When calculating the net energy price to be billed, distribution price (It has been determined by EPDK as $0.1171147 \mathrm{TL} / \mathrm{kWh}$ 
consumption tax (5\% of energy price) are added to unit electricity price. When all taxes and rates are added to the unit price, the price of electricity for household users is calculated as $0,101 \mathrm{E} / \mathrm{kWh}$.

The cost of heat energy in an example geothermal power plant in Turkey is calculated as follows. The amount of heat energy is determined by the calorimeter. This amount of energy is multiplied by the unit price of heat. Then, the apartment share fee, system improvement maintenance and repair fee and VAT are charged to the heat energy price. However, if there is no possibility of using the central heating system water can be heated by electricity. In this case, the cost of heating water with electricity can be calculated by utilizing basic heat formulas. However, this method would be more expensive than obtaining heat from central heating plants. Furthermore, installing a separate heating system will have an additional investment cost.

Heating cost is determined as 0.08 Euro/kWh when using natural gas.

Although the installation costs are decreasing day by day, the economic results will vary from country to country or from year

to year due to the policies of countries, feed-in tariff, interest rate and inflation. Therefore, it should be considered in financial parameters and policies as well as installation costs.

The key input variables required for economic analysis can be classified as geographical, technical and financial. The geographical variables include irradiation, altitude and ambient temperature. These variables were measured with high precision instruments as described in the previous section and used in the calculations.

As a result of the market research, the average cost of whole reference PV/T system was determined to be between 750 and 850 dollars per square meter. This price includes project cost, installation cost and all necessary equipment costs. In this study, the total cost of the PV/T system was taken as 7287 Euros (813.28 Euro per square meter).

The project can be financed with equity, using an amount of bank loan or using bank loan entirely. In this study, it is assumed that bank loans will be used. Therefore, credit interest rates should be determined. The regulations in the energy law allow small and medium-sized enterprises to generate electricity up to $1 \mathrm{MW}$ without licensing and establishing a company. Many banks in Turkey provide loan to small and medium-sized enterprises to produce their own renewable energy. Within this framework, financial support prepared with appropriate maturity and interest rates can be utilized for all turn-key costs such as purchase of equipment, installation and construction. The loan interest rate varies according to the economic conditions of the country. Therefore, it is more appropriate to determine the loan interest rates by taking the average of long years rather than based on the interest rates in the year of installation. Renewable energy loan interest rate in Turkey varies between $4 \%$ and $8 \%$. According to the Turkey Statistical Institute data, considering the annual percentage change in the price index between 2005 and 2019, the average interest rate was $9 \%$ annually (tcmb 2020).

The O\&M cost of the PV/T system may vary depending on the agreements and from country to country. When the literature is examined, it is seen that the O\&M cost of these systems is around $1 \%$ of the total cost of the project (Kalogirou and Tripanagnostopoulos 2006; Rasoul 2017; Gu et al. 2018). When calculating the electrical energy and heat energy produced by 
$\mathrm{PV} / \mathrm{T}$ collectors, it is necessary to consider the annual efficiency loss. Due to the aging of the materials, PV panels lose their

307 efficiency each year compared to the previous year. This value is stated as $0.07 \%$ annually in the manufacturers' catalogs.

308 In this study, the assumed key input parameters are given in Table 4.

Table 4. Input Parameters and Their Ranges for the financial Model

\begin{tabular}{|c|c|c|c|}
\hline Description & Symbol & Average & Unit \\
\hline Electricity Price & & 0.101 & $€ / \mathrm{kWh}$ \\
\hline Heating Price & & 0.08 & $€ / \mathrm{kWh}$ \\
\hline Effective PV/T Area & & 8.96 & $\mathrm{~m}^{2}$ \\
\hline Project Life Cycle & & 25 & Years \\
\hline Electrical Efficiency (STC) & & 13.4 & $\%$ \\
\hline Thermal Efficiency & & 69.3 & $\%$ \\
\hline Degradation Rate & & 0.7 & $\% /$ year \\
\hline Capital Cost & & 7287 & $€ / \mathrm{m}^{2}$ \\
\hline Debt to Equity & & 0.2 & $\%$ \\
\hline Interest Rate & & 6 & $\% /$ year \\
\hline Loan Term & & 25 & Years \\
\hline Effective Tax & & 18 & $\% /$ year \\
\hline Nominal Discount Rate & & 4 & $\% /$ year \\
\hline O\&M Cost & & 1 & $\% /$ year \\
\hline Inflation Rate & & 9 & $\% /$ year \\
\hline
\end{tabular}

\section{TECHNO-ECONOMIC MODELING METHODS}

\section{$312 \quad 4.1$ Thermal Model of PV/T}

313 The performance analysis of the PV/T collector can be performed by evaluating the electrical and thermal efficiency together.

314 Electrical and thermal efficiency affect environmental factors such as irradiation and temperature. For thermal analysis it is

315 necessary to determine the useful heat gain. The useful heat gain represented with equation 1 (Farghally et al. 2015).

$316 Q=A F_{R}\left[(\tau \alpha)_{P V} * G-U_{\text {loss }}\left(T_{i}-T_{a}\right)\right]$

317 Where, $Q$ is the useful heat gain $\left(\mathrm{W} / \mathrm{m}^{2}\right), A$ is the collector area $\left(\mathrm{m}^{2}\right), F_{R}$ is the heat removal efficiency factor, $\tau \alpha$ is the 318 transmittance absorptance product of the $\mathrm{PV}$ cells, $G$ is the irradiation $\left(\mathrm{W} / \mathrm{m}^{2}\right), U_{\text {loss }}$ is the heat loss coefficient $\left(\mathrm{W} / \mathrm{m}^{2 \circ} \mathrm{C}\right), T_{i}$ is

319 the inlet temperature $\left({ }^{\circ} \mathrm{C}\right)$ and the $T_{a}$ is the ambient temperature $\left({ }^{\circ} \mathrm{C}\right)$. The heat removal efficiency factor is calculated using 320 equation 2.

$321 \quad F_{R}=\frac{m c_{p}}{A U_{\text {loss }}}\left[1-\exp \left(-\frac{A U_{\text {loss }} F^{\prime}}{m c_{p}}\right]\right.$

322 Where, $m$ is the mass flow rate in the collector (lps), $C_{p}$ is the collector cooling medium and $F^{\prime}$ is the corrected fin efficiency.

323 The corrected fin efficiency and the fin efficiency $(F)$ are calculated with equation 3 and 4 respectively.

$324 \quad F^{\prime}=\left[\frac{\frac{1}{U_{\text {loss }}}}{U_{\text {loss }}(d+(w-d) F)}\right]+\frac{1}{w h_{P V A}}+\frac{1}{\pi d h_{\text {fluid }}}$

$325 \quad F=\frac{\tanh \left(M \frac{w-d}{2}\right)}{M \frac{w-d}{2}}$ 
326 Where, $M$ is the coefficient term which accounts for the thermal conductivity of the absorber and PV cell, $w$ is the tube spacing

$327(\mathrm{~m}), d$ is the diameter of the tube $(\mathrm{m}), h_{\text {fluid }}$ is the heat transfer coefficient of fluid $\left(\mathrm{W} / \mathrm{m}^{2 \circ} \mathrm{C}\right)$ and $h_{P V A}$ is the heat transfer 328 coefficient $\left(\mathrm{W} / \mathrm{m}^{2 \circ} \mathrm{C}\right)$. The $M$ is determined using equation 5 .

$329 \quad M=\sqrt{\frac{U_{\text {loss }}}{k_{a b s} l_{a b s}+k_{P V} l_{P V}}}$

330 The loss coefficient $\left(\mathrm{U}_{\text {loss }}\right)$ can be divided to three parts. These are the top loss coefficient $\left(U_{t}\right)$, bottom loss coefficient $\left(U_{b}\right)$ and 331 the edge loss coefficient $\left(U_{e}\right)$. These loss coefficients can be calculated using equations 6, 7, 8 and 9.

$332 U_{\text {loss }}=U_{t}+U_{b}+U_{e}$

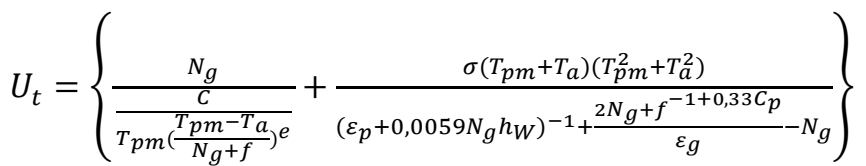

$334 U_{b}=\frac{K_{b}}{L_{b}}$

$335 U_{e}=\frac{(U A)_{e d g e}}{A_{c}}$

336 In order to calculate the loss coefficient, it is necessary to determine the value of $c, e, f, h w, U A$ and $T_{p m}$. These parameters are 337 calculated with following equations.

$338 c=520\left(1-0,000051 \beta^{2}\right)$

$339 e=0,43\left(1-\frac{100}{T_{p m}}\right)$

340

$\left.f=0(1+0,089)^{h_{W}}-0,1166 h_{W} \varepsilon_{p}\right)(1+0,07866 N)$

$341 h_{W}=5,7+3,8 v$

342

$T_{p m}=T_{i}+\frac{\frac{Q u}{A_{e}}}{F_{R} U_{L}}\left(1-F_{R}\right)$

343 Where, $\mathrm{Ng}$ is the number of covered glass, $\varepsilon_{p}$ is the plate emittiance, $\varepsilon_{g}$ is the glass emittance, $T_{p m}$ is the mean plate

344 temperature, $h_{W}$ is the wind transfer coefficient, $v$ is the wind speed, $\beta$ is the tilt angel of collector, $p$ is the collector perimeter 345 and $L$ is the absorber thickness.

346 From using above equation, it is possible to calculate the thermal and electrical efficiency of PV/T collector. The thermal

347 efficiency can be expressed as a function of the inlet temperature, ambient temperature and irradiation, while the electrical

348 efficiency can be expressed as a function of the nominal operating cell temperature (NOCT) and $T_{p m}$. Equation 14 and 15 349 expressed thermal and electrical efficiency respectively.

$\eta_{\text {thermal }}=F_{R}\left(S * \tau \alpha_{P V}\right)+\left(1-S * \tau \alpha_{T}\right)-F_{R} U_{\text {loss }} \frac{T_{i}-T_{a}}{G}$

351

$\eta_{e}=0,15\left(1-0,005\left(T_{p m}-N O C T\right)\right)$ 


\subsection{Electrical Energy Model of the PV/T}

The PV panels convert solar irradiation into the direct current. However, most devices used in the daily life run with the alternating current. Therefore, the voltage produced in PV panels must be converted to alternating voltage. In addition, maximum power point tracker (MPPT) is required in order to operate the PV panel at maximum power point under all conditions. Otherwise, if the system is off-grid, a storage device is needed. Although the electrical energy produced in PV panels depends on a large amount of radiation, panel area and panel efficiency also affect the amount of energy to be produced.

The hourly energy generated by the PV panel is calculated using equation 17.

$E_{A, h}=G_{I, h} \cdot A_{a} \cdot \eta_{P V}$

Where the $G_{I, h}$ is the hourly total in-plane irradiance $\left(\mathrm{kWh} / \mathrm{m}^{2}\right), A_{a}$ is the PV/T available area $\left(\mathrm{m}^{2}\right)$ and $\eta_{P V}$ is the overall PV system efficiency (\%). The overall PV system efficiency varies depending on many factors such as the PV panel efficiency $\left(\mathrm{\eta}_{\text {module }}\right)$, inverter efficiency $\left(\mathrm{\eta}_{\text {inv }}\right)$, the PV panel temperature efficiency $\left(\mathrm{\eta}_{\text {temp }}\right)$, power conditioning efficiency $\left(\mathrm{\eta}_{p c}\right)$ and the annual PV module degradation $\left(\eta_{d}\right)$. The overall PV panel efficiency is calculated with equation 18.

$\eta_{P V}=\eta_{\text {module }} \cdot \eta_{p c} \cdot \eta_{t e m p} \cdot \eta_{i n v} \cdot\left(1-(t-1) \cdot \eta_{d}\right)$

where $t$ is the index for years. The output DC energy of the PV panel, hence the panel efficiency decreases linearly with increasing temperature. This efficiency depends on the temperature power coefficient $(\beta)$ of the panel and the cell temperature $\left(T_{c, h}\right)$.

$\eta_{\text {temp }}=\left[1-\beta\left(T_{c, h}-T_{c, r e f}\right)\right]$

The cell temperature also varies depending on the ambient temperature $\left(T_{a, h}\right)$, irradiation and (NOCT).

$T_{c, h}=T_{a, h}+[(N O C T-20) / 800] \cdot H_{I, h}$

$\beta$ and NOCT vary according to panel technology and are determined from PV panel catalogs.

\subsection{Economic Analysis Model}

In this study, it is aimed to determine the LCOE, NPV and PBP values by economic analysis of the PV/T system. LCOE is a widely accepted index which is indicates the total unit energy cost of installing and operating an energy system over its lifetime. Since LCOE represents the unit cost of generated electricity, it enables economic comparison of different energy generation technologies and the installation of similar systems in different regions. LCOE should contain many factors such as investment costs, financial costs, fuel costs, revenues and energy production amount during its lifetime. The formula of LCOE is given in equation 21 .

$$
L C O E=\sum_{j=0}^{n-1} \frac{C_{t}}{(1+r)^{t}} / \sum_{t=0}^{n-1} \frac{E_{t}}{(1+r)^{t}}
$$

381 where $C_{t}$ is the total cost in the year of $\mathrm{t}(€), n$ is the lifetime of the PV/T (year) and $r$ is the discount rate (\%). 
382 The total cost of PV/T system contains investment expenditures in the initial year, financing loan cost $\left(L_{t}\right)$, operating and 383 management cost $\left(O M_{t}\right)$ and tax paid for energy generation $\left(T_{a, t}\right)$.

$384 C_{t}=I_{0}+L_{t}+O M_{t}+T_{a, t}$

385 Investment expenditure is the capital investment provided by the proprietor. It depends on the debt to equity ratio in

386 accordance with the agreement with the bank. The investment expenditure for the first year is calculated by equation 23 .

$387 \quad I_{0}=C_{0} x(1-D E)$

388 Where $C_{0}$ is the capital cost $(€)$ and $\mathrm{DE}$ is the dept to equity ratio (\%).

389 The loan cost is equal to the sum of the annual invested capital with the interest rate on the invested capital.

$390 \quad L_{t}=C_{0} \cdot D E / n+C_{0} \cdot D E(1-t / n) \cdot I_{t r}$

391 Where $\mathrm{Itr}_{t}$ is the interest rate in the year $\mathrm{t}(\%)$.

392 Another method used to evaluate a project, measure economic efficiency and make decisions is NPV. Probably the most 393 popular method among the all methods is the NPV and it is considered the most theoretically reliable. The NPV involves 394 discounting all future cash flows (both in- and out-flow) at a discount rate and then combining them. The NPV can be defined 395 in one formulation. The required historical data to calculate the NPV can be obtained from public sources, engineering 396 documents, and past projects. By using historical data, the approximate probability density of costs, benefits, and discount 397 factors can be formulated for the expected life of the project. Thereby, uncertainty in the project economy is taken into 398 consideration. The NPV can be defined by equation 25 (Žižlavský 2014; Marchioni and Magni 2018; Heyd 2018).

$399 N P V=-C_{0}+\sum_{t=0}^{n-1} \frac{C F_{t}}{(1+r)^{t}}$

400 Where $C F_{t}$ is the cash flow of the year $\mathrm{t}(€)$. The $C F_{t}$ can be calculating by equation 26

$401 \quad C F_{t}=S_{e t}+S_{t h t}-C_{t}$

$402 S_{e t}$ and $S_{t h t}$ describe the electrical and thermal energy savings respectively. $S_{e t}$ and $S_{t h t}$ can be calculated by using equations 40327 and 28.

$404 S_{e t}=E P_{t} \cdot E_{e t} \cdot\left(1+I f r_{t}\right)$

$S_{t h t}=H P_{t} \cdot E_{t h t} \cdot\left(1+I f r_{t}\right)$

406 Where $E P_{t}$ is the electricity price in the year $\mathrm{t}(€ / \mathrm{kWh}), H P_{t}$ is the heating price in the year $\mathrm{t}(€ / \mathrm{kWh})$, If $r_{t}$ is the inflation rate 407 in the year $\mathrm{t}$.

408 The payback period (PBP) is the simplest investment appraisal method. The PBP refers to the required time to offset the initial cash outflow by cash inflows generated by a project. In most cases, a longer PBP means a less lucrative investment, while a shorter PBP means that the capital cost can get back earlier. There are two ways to calculate the PBP, the averaging method and subtraction method. The averaging method is used when cash flows are expected to be steady in subsequent years and the subtraction method is used when cash flows are expected to vary in subsequent years. Due to various factors such as variable 
413 inflation and loan interest rates, the long PBP makes the investment risky (Imteaz and Ahsan 2018; Lawrence et al. 2019). The

414 equation 29 can be used to define the PBP.

$415 \quad P B P=T_{C F_{t}} \geq 0$

\section{6}
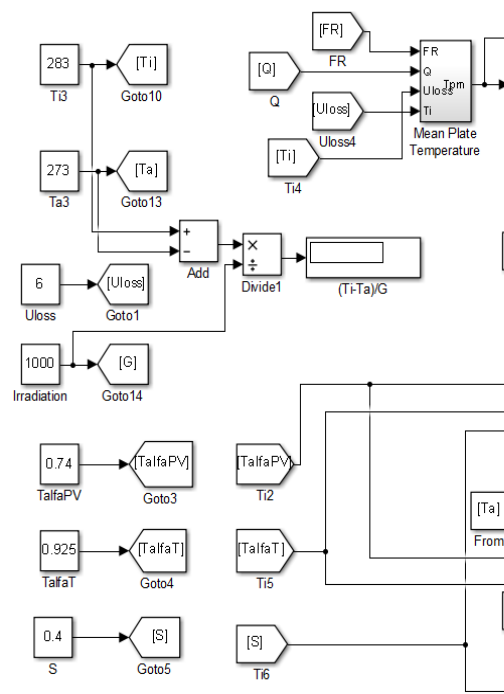

\subsection{MATLAB/Simulink Model of the PV/T Collector}

The model of the PV/T collector was created using MATLAB/Simulink program by considering all above-mentioned parameters in order to analysis the performance of the PV/T. All these parameters such as ambient temperature, emittance of plate, number of tubes, number of cells, collector area, absorber thickness, heat transfer coefficient etc. affect the PV/T collector performance. The simulink program allows us to analysis how these parameters changes affect the thermal and electrical efficiency. Figure 2 shows the simulink model of the PV/T collector.
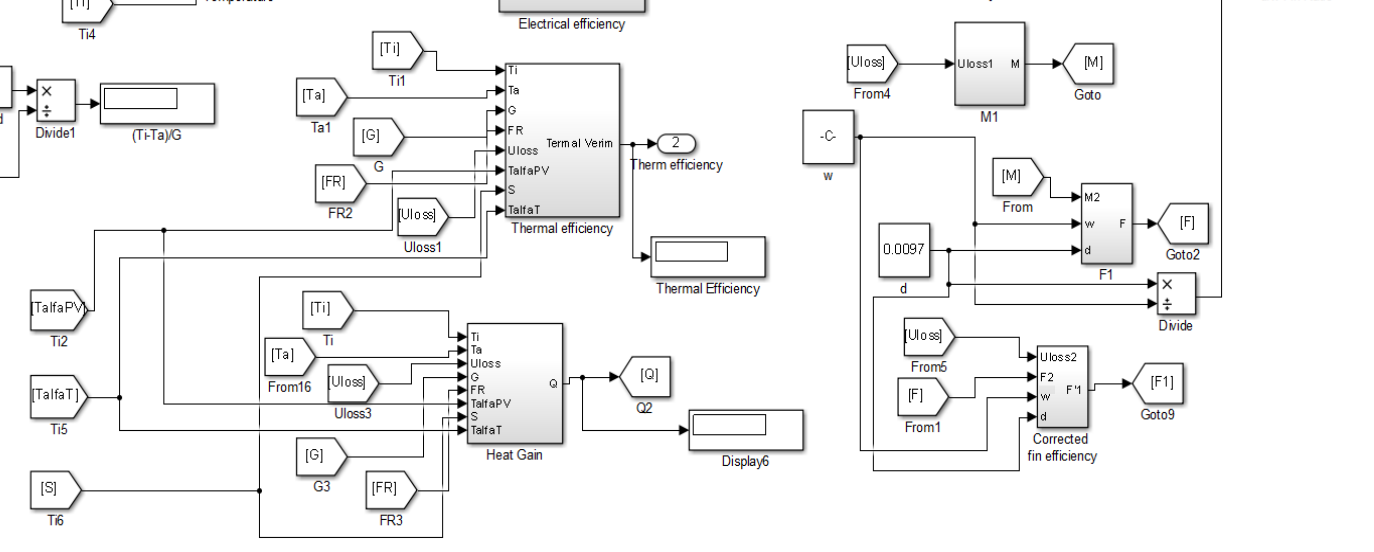

Fig. 2. MATLAB/Simulink Model of the PV/T Collector

\section{RESULTS}

There are several factors that influence the thermal and electrical efficiency of the PV/T collector, such as mass flow rate, absorbent plate parameters (such as tube spacing, pipe diameter, and fin thickness), thermal conductivity of the fluid in the absorbent plate, packing factor inlet temperature and irradiation. Although $s$ and $\tau \alpha_{\mathrm{pv}}$ are effective on electrical and thermal efficiency, these are taken as a constant value since they are the coefficients of the materials used in the PV/T collector. However, the effect of $\mathrm{s}$ and $\tau \alpha_{\mathrm{pv}}$ on the electrical and thermal efficiency is shown in figure 3 . The increases of the $s$ means that more collector areas are covered by PV cells. Therefore, the increase of the absorber block area has the effect of decreasing the heat increase in PV cells. This means that more areas are heated under the same irradiation. Therefore, a decrease in thermal efficiency will occur due to the $s$.

So, increasing the $s$ increases the electrical efficiency and decreases the thermal efficiency. Therefore, an optimal value for the 
$s$ should be determined. The wavelength of the light that a typical PV cell absorbs smaller than the wavelength of the light that the thermal collector absorbs. Therefore, large wavelength lights are reflected from the PV cell and absorbed by the thermal collector. Therefore, increasing the $\tau \alpha_{\mathrm{pv}}$ increases the thermal efficiency. Since $\tau \alpha_{\mathrm{pv}}$ has little effect on electrical efficiency, it is preferred that $\tau \alpha_{\mathrm{pv}}$ is close to 1 .
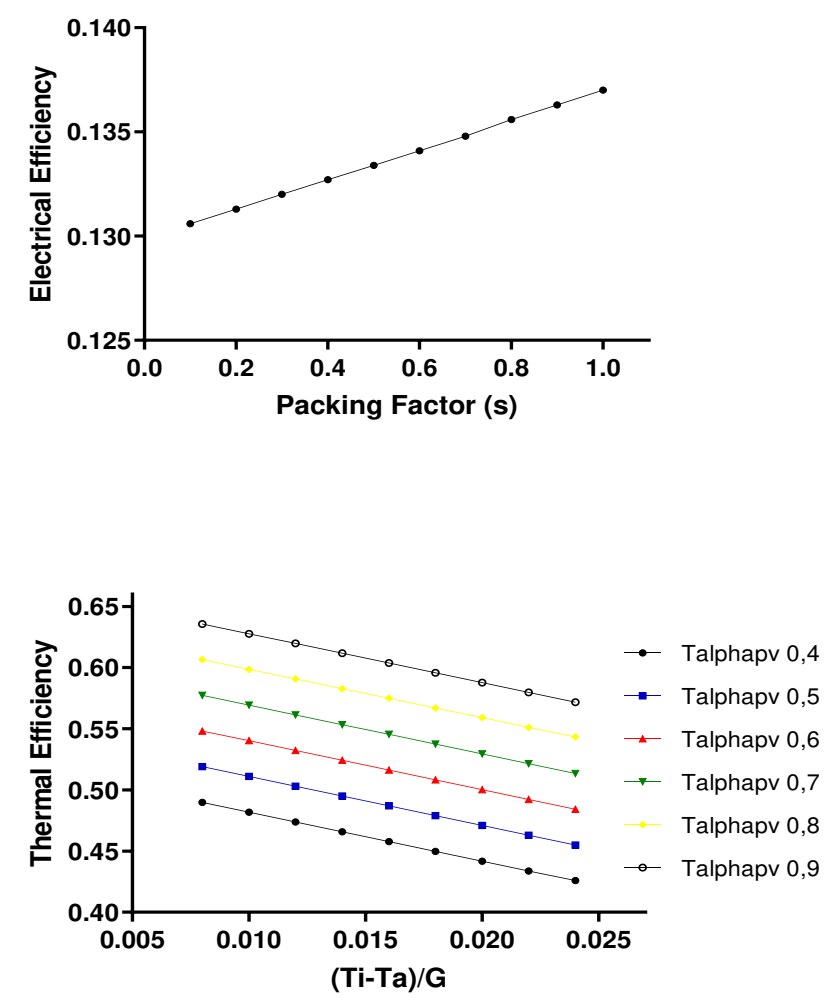

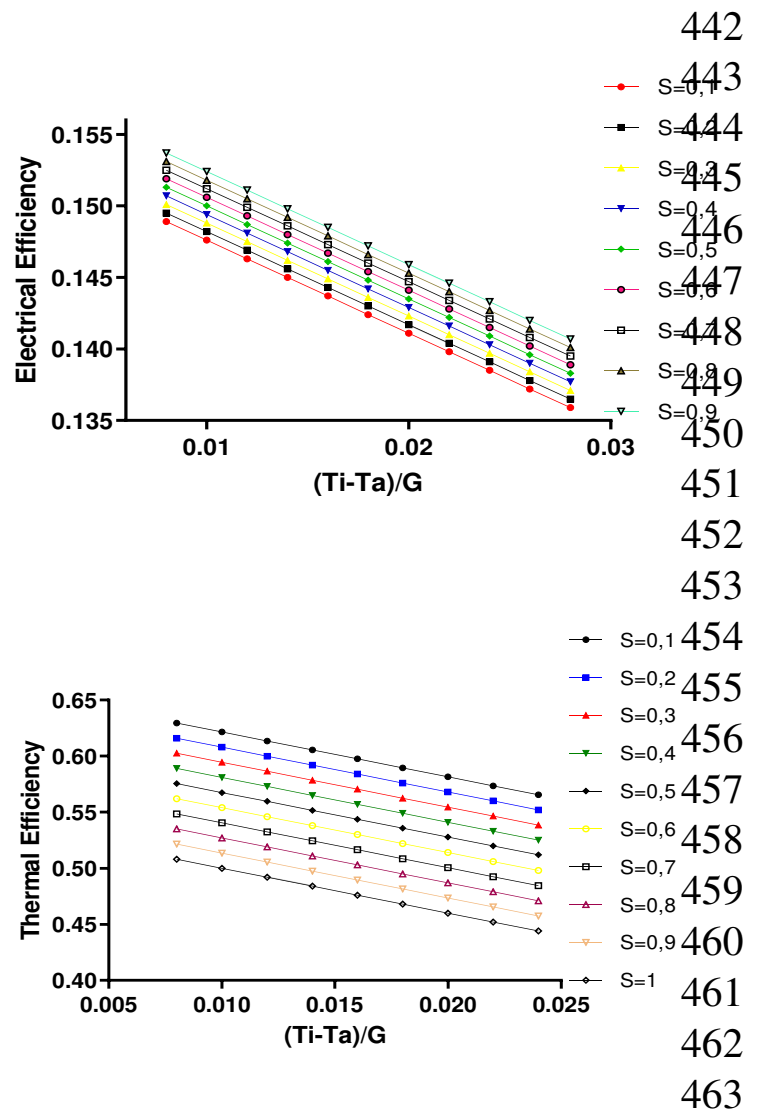

Fig. 3. The effect of the $s$ and $\tau \alpha_{\mathrm{pv}}$ on the performance of the electrical and thermal efficiency

The aim of this simulink model is to determine the thermal and electrical efficiency of the PV/T collector depending on the temperature and irradiation. In this study, in order to examine the effect of the temperature and irradiation on the electrical and thermal efficiency, $\tau \alpha_{\mathrm{pv}}$ and $s$, was kept constant at 0.8 and s 0.4 , respectively. Thus, only the effect of the temperature and irradiation on the efficiency was observed. As shown in Figure 3, the increase in (Ti-Ta)/G decreases both the electrical and thermal efficiency. 


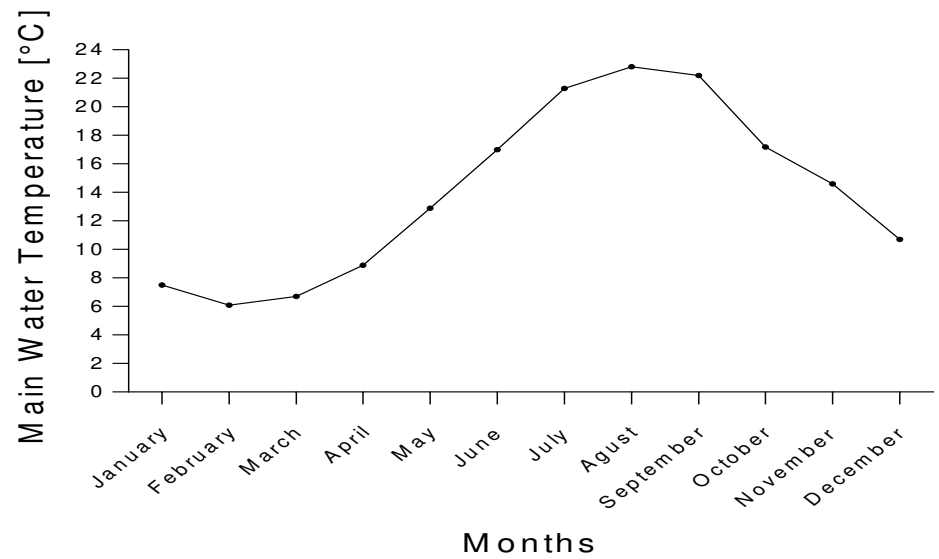

Fig. 4. Mains Water Temperature

475 Mains water temperature is associated with soil temperature. As the temperature of the soil does not change as fast as the ambient temperature, mains water temperature does not change very fast. Therefore, it has been found appropriate to use monthly average mains water temperature.

In this study, the electrical and thermal efficiency of the PV/T were calculated by using the temperature and irradiation data taken at 15-minute intervals. Hourly average irradiation and the ambient temperature are shown in Figure 5. However, the data which are recorded at 15 -minute intervals were used in calculation. The reason for showing hourly average values is to be able to draw plainer and more understandable graph.
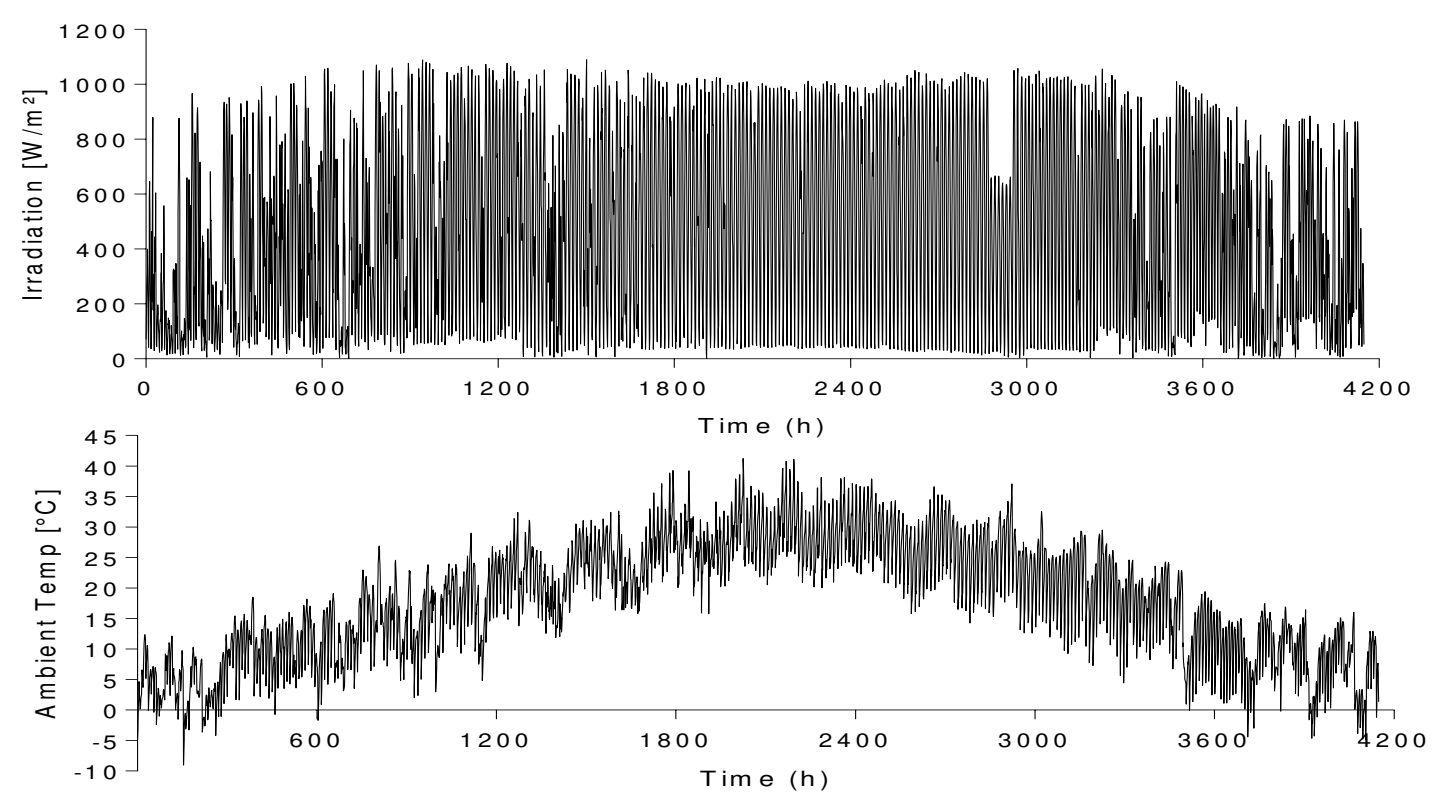

Fig. 5. Hourly average irradiation and ambient temperature

484 The lowest ambient temperature and PV cell temperature were measured in January at $-9.7^{\circ} \mathrm{C}$ and $-8.42{ }^{\circ} \mathrm{C}$, respectively. The 
monthly average minimum ambient temperature and PV cell temperature were measured in January at $3.78{ }^{\circ} \mathrm{C}$ and $8.6{ }^{\circ} \mathrm{C}$, respectively. The monthly maximum ambient temperature and PV cell temperature were measured at $29.61{ }^{\circ} \mathrm{C}$ and $37.55^{\circ} \mathrm{C}$, respectively, in July. Table 5 shows the minimum, maximum and average temperature values of PV cells and media.

Table 5. Minimum, Maximum and Average PV Cell and Ambient Temperature

\begin{tabular}{|c|c|c|c|c|c|c|}
\hline Months & $\begin{array}{c}\text { Min. } \\
\text { Ambient } \\
\text { Temp. }\left({ }^{\circ} \mathrm{C}\right)\end{array}$ & $\begin{array}{c}\text { Min. PV } \\
\text { Cell } \\
\text { Temp. }\left({ }^{\circ} \mathrm{C}\right)\end{array}$ & $\begin{array}{c}\text { Max } \\
\text { Ambient } \\
\text { Temp. }\left({ }^{\circ} \mathrm{C}\right)\end{array}$ & $\begin{array}{c}\text { Max PV } \\
\text { Cell Temp. } \\
\left({ }^{\circ} \mathrm{C}\right)\end{array}$ & $\begin{array}{c}\text { Average Monthly } \\
\text { Ambient Temp. } \\
\left({ }^{\circ} \mathrm{C}\right)\end{array}$ & $\begin{array}{c}\text { Average Monthly } \\
\text { PV Cell Temp. } \\
\left({ }^{\circ} \mathrm{C}\right)\end{array}$ \\
\hline January & -9.7 & -8.42 & 13.3 & 14.99 & 3.78 & 8.6 \\
\hline February & -2.1 & -2.11 & 18.56 & 45.38 & 10.08 & 18.72 \\
\hline March & -2.43 & -2.61 & 27.07 & 49.72 & 13.09 & 21.04 \\
\hline April & 1.61 & -0.79 & 32.05 & 54.77 & 17.42 & 28.22 \\
\hline May & 10.99 & 9.26 & 34.33 & 57.74 & 22.55 & 31.6 \\
\hline June & 14.99 & 10.42 & 42.78 & 60.19 & 27.41 & 35.46 \\
\hline July & 18.25 & 14.77 & 42.44 & 57.77 & 29.61 & 37.55 \\
\hline August & 11.52 & 8.83 & 37.28 & 58.24 & 26.65 & 35.67 \\
\hline September & 6.77 & 2.86 & 38.04 & 57.96 & 22.69 & 32.98 \\
\hline October & -0.48 & -2.37 & 27.88 & 54.1 & 16.4 & 26.84 \\
\hline November & -5.01 & -7.98 & 18.47 & 41.54 & 10.1 & 19.04 \\
\hline December & -5.83 & -8.59 & 17.03 & 41.02 & 7.09 & 15.73 \\
\hline
\end{tabular}

In the MATLAB/simulink model, the electrical and thermal efficiency of the PV/T collector was determined using hourly data.

These data were used when calculating the electrical and thermal energy production values of PV/T collector. Thermal efficiency is significantly affected by the inlet water temperature, ambient temperature and the irradiation, while the electrical efficiency is significantly affected by the panel cell temperature. The thermal and electrical efficiency of the PV/T collector are shown in Figure 6. Annual average thermal and electrical efficiency was calculated as $69.3 \%$ and $13.4 \%$, respectively.

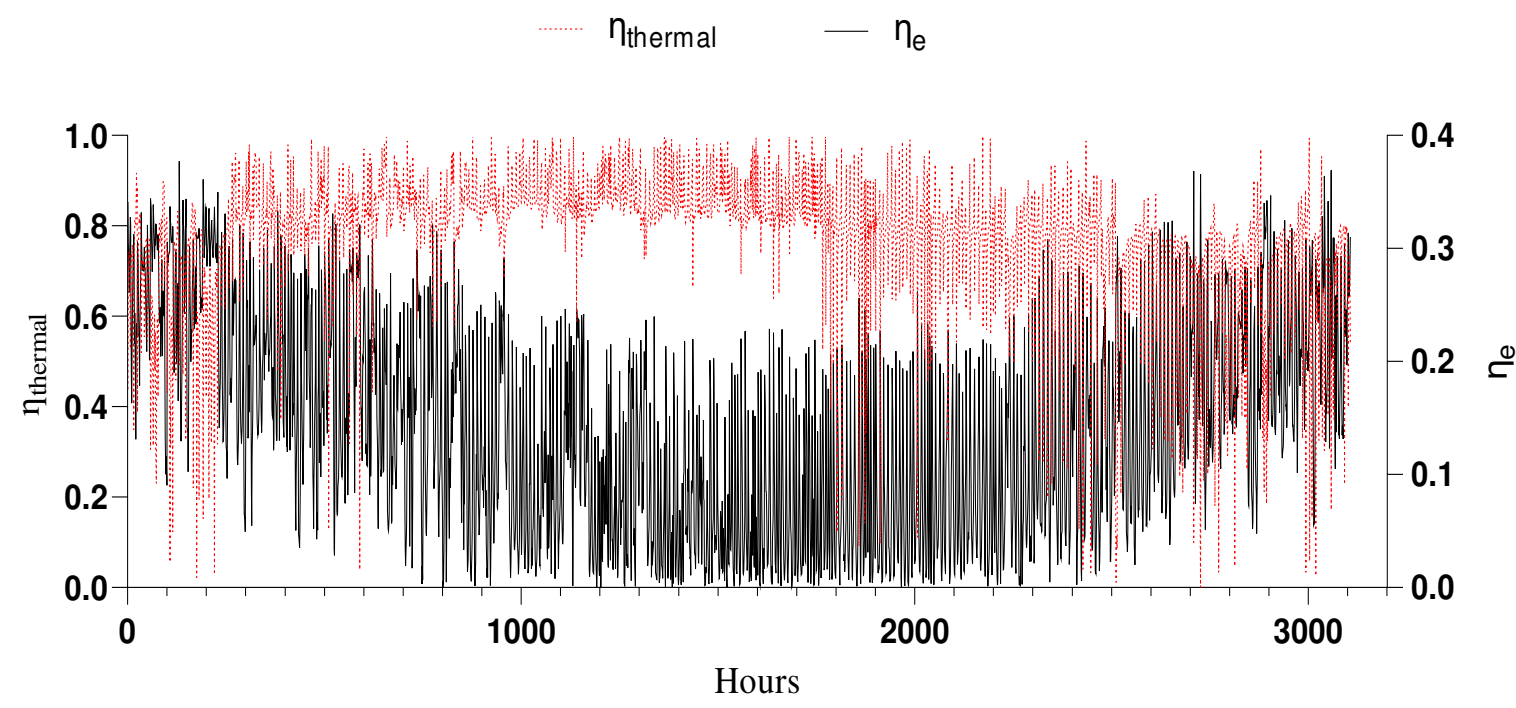

Fig.6. Thermal and electrical efficiency of the PV/T collector

In order to meet the annual energy needs of the reference house, seven PV/T collectors should be used. Accordingly, the amount of electrical energy and heat energy produced by the designed PV/T system was calculated on an hourly basis. While calculating on an hourly basis, the current efficiency value of the PV/T collector was taken into consideration. It has been 
501 calculated from the system that it will generate $2333.18 \mathrm{kWh}$ of electrical energy and $10864.43 \mathrm{kWh}$ of heat energy for the first 502 year. Figure 7 shows the amount of electricity and heat energy that the system will generate on an hourly basis.
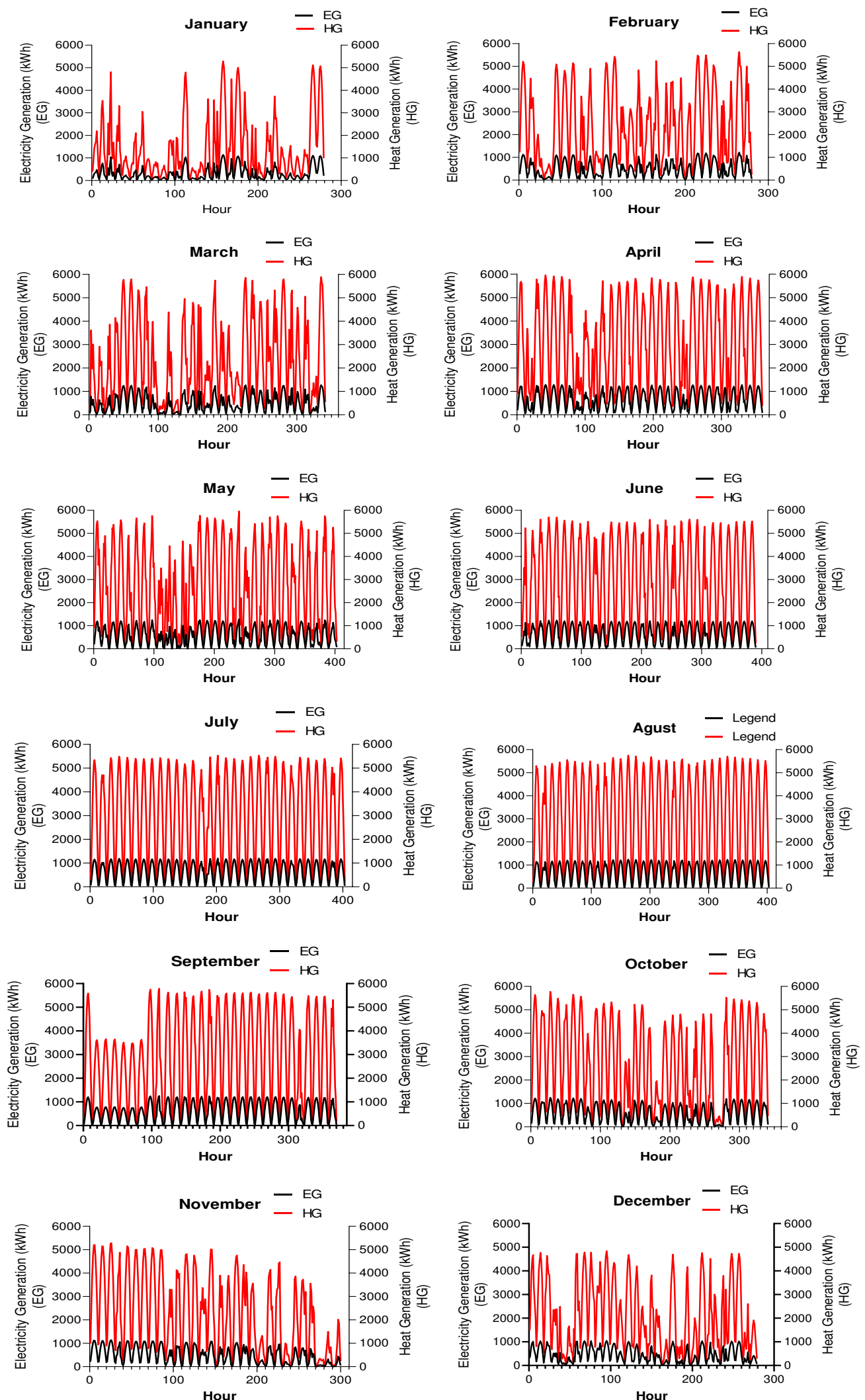

Fig.7. Monthly Electricity and Heat Generation 
511 Table.6. shows the estimated financial results of the PV/T system over its 25-year economic life. In the economic analysis, the

512 degradation rate of the panel and the electricity consumption of the pump were taken into consideration.

Table 6. The Estimation of Financial Results During the Life Cycle of PV/T System

\begin{tabular}{|c|c|c|c|c|c|c|c|c|c|c|c|c|c|}
\hline Year & 0 & 1 & 2 & 3 & 4 & 5 & 6 & 7 & 8 & 9 & 10 & 11 & 12 \\
\hline \multicolumn{14}{|c|}{ Cost saving from energy generation } \\
\hline Electricity generation & 2333.2 & 2316.8 & 2300.6 & 2284.5 & 2268.5 & 2252.7 & 2236.9 & 2221.2 & 2205.7 & 2190.2 & 2174.9 & 2159.7 & 2144.6 \\
\hline Electric Pump Consumption & 511 & 511 & 511 & 511 & 511 & 511 & 511 & 511 & 511 & 511 & 511 & 511 & 511 \\
\hline Totol electricity generation & 1822.2 & 1805.8 & 1789.6 & 1773.5 & 1757.5 & 1741.7 & 1725.9 & 1710.2 & 1694.7 & 1679.2 & 1663.9 & 1648.7 & 1633.6 \\
\hline Heat generation & 10864 & 10788 & 10713 & 10638 & 10563 & 10489 & 10416 & 10343 & 10271 & 10199 & 10127 & 10057 & 9986.1 \\
\hline Electricity savings & 184.04 & 198.81 & 197.02 & 195.25 & 193.49 & 191.74 & 190 & 188.28 & 186.57 & 184.87 & 183.18 & 181.5 & 179.84 \\
\hline $\begin{array}{l}\text { Heating savings } \\
\text { TOTAL ENERGY }\end{array}$ & 869.15 & 940.75 & 934.16 & 927.62 & 921.13 & 914.68 & 908.28 & 901.92 & 895.61 & 889.34 & 883.11 & 876.93 & 870.79 \\
\hline $\begin{array}{l}\text { GENERATION } \\
\text { TOTAL ENERGY }\end{array}$ & 13198 & 13105 & 13013 & 12922 & 12832 & 12742 & 12653 & 12564 & 12476 & 12389 & 12302 & 12216 & 12131 \\
\hline SAVING & 1053.2 & 1139.6 & 1131.2 & 1122.9 & 1114.6 & 1106.4 & 1098.3 & 1090.2 & 1082.2 & 1074.2 & 1066.3 & 1058.4 & 1050.6 \\
\hline \multicolumn{14}{|c|}{ Cost of operation \& Maintenance and Tax } \\
\hline OM cost & 72.87 & 72.87 & 72.87 & 72.87 & 72.87 & 72.87 & 72.87 & 72.87 & 72.87 & 72.87 & 72.87 & 72.87 & 72.87 \\
\hline Tax for electricity & 33.127 & 35.785 & 35.464 & 35.145 & 34.828 & 34.513 & 34.2 & 33.89 & 33.582 & 33.276 & 32.972 & 32.671 & 32.371 \\
\hline TOTAL (Omt) & 106 & 108.66 & 108.33 & 108.01 & 107.7 & 107.38 & 107.07 & 106.76 & 106.45 & 106.15 & 105.84 & 105.54 & 105.24 \\
\hline \multicolumn{14}{|l|}{ Financial cost } \\
\hline Loan payment & 58.296 & 58.296 & 58.296 & 58.296 & 58.296 & 58.296 & 58.296 & 58.296 & 58.296 & 58.296 & 58.296 & 58.296 & 58.296 \\
\hline Loan interest & 87.444 & 83.946 & 80.448 & 76.951 & 73.453 & 69.955 & 66.457 & 62.96 & 59.462 & 55.964 & 52.466 & 48.969 & 45.471 \\
\hline TOTAL (Lt) & 145.74 & 142.24 & 138.74 & 135.25 & 131.75 & 128.25 & 124.75 & 121.26 & 117.76 & 114.26 & 110.76 & 107.26 & 103.77 \\
\hline \multicolumn{14}{|c|}{ Discounted cash flow and energy generation } \\
\hline Net Profit $(\mathrm{CFt})$ & -5028 & 888.66 & 884.1 & 879.61 & 875.17 & 870.79 & 866.46 & 862.18 & 857.96 & 853.8 & 849.69 & 845.63 & 841.62 \\
\hline $\begin{array}{l}\text { Discounted Cost }(\mathrm{Ct}) \\
\text { Discounted Energy }\end{array}$ & 6081.3 & 250.9 & 247.08 & 243.26 & 239.45 & 235.63 & 231.82 & 228.02 & 224.21 & 220.41 & 216.6 & 212.81 & 209.01 \\
\hline Generation & 13198 & 12601 & 12032 & 11488 & 10969 & 10473 & 9999.8 & 9547.9 & 9116.4 & 8704.4 & 8311 & 7935.4 & 7576.8 \\
\hline Cash Flow & -5028 & -4139 & -3255 & -2376 & -1501 & -629.8 & 236.64 & 1098.8 & 1956.8 & 2810.6 & 3660.3 & 4505.9 & 5347.5 \\
\hline
\end{tabular}

\begin{tabular}{|c|c|c|c|c|c|c|c|c|c|c|c|c|}
\hline Year & 13 & 14 & 15 & 16 & 17 & 18 & 19 & 20 & 21 & 22 & 23 & 24 \\
\hline \multicolumn{13}{|c|}{ Cost saving from energy generation } \\
\hline Electricity generation & 2129.6 & 2114.6 & 2099.8 & 2085.1 & 2070.5 & 2056.1 & 2041.7 & 2027.4 & 2013.2 & 1999.1 & 1985.1 & 1971.2 \\
\hline Electric Pump Consumption & 511 & 511 & 511 & 511 & 511 & 511 & 511 & 511 & 511 & 511 & 511 & 511 \\
\hline Totol electricity generation & 1618.6 & 1603.6 & 1588.8 & 1574.1 & 1559.5 & 1545.1 & 1530.7 & 1516.4 & 1502.2 & 1488.1 & 1474.1 & 1460.2 \\
\hline Heat generation & 9916.2 & 9846.8 & 9777.9 & 9709.5 & 9641.5 & 9574 & 9507 & 9440.4 & 9374.4 & 9308.7 & 9243.6 & 9178.9 \\
\hline Electricity savings & 178.19 & 176.55 & 174.92 & 173.3 & 171.69 & 170.1 & 168.51 & 166.94 & 165.37 & 163.82 & 162.28 & 160.75 \\
\hline $\begin{array}{l}\text { Heating savings } \\
\text { TOTAL ENERGY }\end{array}$ & 864.7 & 858.64 & 852.63 & 846.66 & 840.74 & 834.85 & 829.01 & 823.21 & 817.44 & 811.72 & 806.04 & 800.4 \\
\hline $\begin{array}{l}\text { GENERATION } \\
\text { TOTAL ENERGY }\end{array}$ & 12046 & 11961 & 11878 & 11795 & 11712 & 11630 & 11549 & 11468 & 11388 & 11308 & 11229 & 11150 \\
\hline SAVING & 1042.9 & 1035.2 & 1027.5 & 1020 & 1012.4 & 1004.9 & 997.52 & 990.14 & 982.82 & 975.54 & 968.32 & 961.15 \\
\hline \multicolumn{13}{|c|}{ Cost of operation \& Maintenance and Tax } \\
\hline $\mathrm{OM}$ cost & 72.87 & 72.87 & 72.87 & 72.87 & 72.87 & 72.87 & 72.87 & 72.87 & 72.87 & 72.87 & 72.87 & 72.87 \\
\hline Tax for electricity & 32.074 & 31.778 & 31.485 & 31.194 & 30.904 & 30.617 & 30.332 & 30.049 & 29.767 & 29.488 & 29.211 & 28.936 \\
\hline TOTAL (Omt) & 104.94 & 104.65 & 104.35 & 104.06 & 103.77 & 103.49 & 103.2 & 102.92 & 102.64 & 102.36 & 102.08 & 101.81 \\
\hline \multicolumn{13}{|l|}{ Financial cost } \\
\hline Loan payment & 58.296 & 58.296 & 58.296 & 58.296 & 58.296 & 58.296 & 58.296 & 58.296 & 58.296 & 58.296 & 58.296 & 58.296 \\
\hline Loan interest & 41.973 & 38.475 & 34.978 & 31.48 & 27.982 & 24.484 & 20.987 & 17.489 & 13.991 & 10.493 & 6.9955 & 3.4978 \\
\hline TOTAL $(\mathrm{Lt})$ & 100.27 & 96.771 & 93.274 & 89.776 & 86.278 & 82.78 & 79.283 & 75.785 & 72.287 & 68.789 & 65.292 & 61.794 \\
\hline \multicolumn{13}{|c|}{ Discounted cash flow and energy generation } \\
\hline Net Profit $(\mathrm{CFt})$ & 837.67 & 833.77 & 829.92 & 826.12 & 822.38 & 818.68 & 815.03 & 811.44 & 807.89 & 804.4 & 800.95 & 797.55 \\
\hline $\begin{array}{l}\text { Discounted Cost }(\mathrm{Ct}) \\
\text { Discounted Energy }\end{array}$ & 205.21 & 201.42 & 197.63 & 193.84 & 190.05 & 186.27 & 182.48 & 178.7 & 174.92 & 171.15 & 167.37 & 163.6 \\
\hline Generation & 7234.4 & 6907.5 & 6595.3 & 6297.2 & 6012.6 & 5740.9 & 5481.5 & 5233.8 & 4997.2 & 4771.4 & 4555.8 & 4349.9 \\
\hline Cash Flow & 6185.2 & 7019 & 7848.9 & 8675 & 9497.4 & 10316 & 11131 & 11943 & 12750 & 13555 & 14356 & 15153 \\
\hline \multicolumn{13}{|l|}{ Evaluation Metrics } \\
\hline NPV & 7905.3 & & & & & & & & & & & \\
\hline LCOE & 0.0467 & & & & & & & & & & & \\
\hline Payback Period & 6 year & & & & & & & & & & & \\
\hline
\end{tabular}


515 It is seen that the economic performance is good and acceptable for the market, where LCOE is calculated at $0.0467 € / \mathrm{kWh}$

516 while NPV and PP are respectively estimated at $7905.3 €$ and 6 years. PV/T systems are not yet widely used in daily life.

517 Therefore, initial investment costs are still high. However, PV/T systems are still economically viable today. While performing

518 this economic analysis, input variables are determined by taking the average of the values under current conditions. In 519 particular, inflation and changes in the Euro exchange rate may change the economic analysis results. In order to minimize the

520 impact of these changes, both variables have been averaged over many years and the future perspectives of various institutions

521 according to the current conditions have been considered.

\section{CONCLUSIONS}

524 Turkey is the country with the highest potential in Europe in terms of radiation and sunshine duration. For these reasons, both 525 electrical energy and thermal energy supply from solar energy is increasing rapidly. Since the consumption of energy at the 526 place where it is produced reduces losses, distributed power plants have started to be preferred instead of central long-distance 527 power plants. The easiest way to build a distributed power plant is to utilize solar energy. With the developing technology and 528 the decrease in costs, solar energy applications are seen in many buildings. However, these systems are often installed 529 separately either to obtain thermal energy or to obtain electrical energy. However, there is very limited space for the 530 installation of such systems in buildings. For this reason, it may be more appropriate to install PV/T-based systems that can 531 generate electricity and thermal energy at the same time. The available literature provides scarce information about the 532 performance and economic analysis of PV/T based systems. In this study, for the first time in Turkey, the performance and 533 economic analysis were performed using real meteorological data's. It is aimed to provide hot water and electrical energy of a 534 house by using water-based PV/T collectors. The results of this study are briefly summarized below.

535 - The ambient temperature of the region changes from -9.7 to $42.78{ }^{\circ} \mathrm{C}$. The PV cell temperature changes from -8.42 to $53660.19^{\circ} \mathrm{C}$

537 - Annual average thermal and electrical efficiency was calculated as $69.3 \%$ and $13.4 \%$, respectively.

538 - The system can generate $2333.18 \mathrm{kWh}$ of electrical energy and $10864.43 \mathrm{kWh}$ of heat energy for the first year.

$539-$ The LCOE was calculated at $0.0467 € / \mathrm{kWh}$ while NPV and PP are respectively estimated at $7905.3 €$ and 6 years.

540 It is expected that this study and its results will lead to the use of PV/T based systems in buildings. Also, it is clear that the 541 results will contribute to the literature. 


\section{Declarations}

\section{Ethics approval and consent to participate}

$548 \quad$ Not applicable

549 Consent for publication

$550 \quad$ Not applicable

$551 \quad$ Availability of data and materials

552 The datasets generated and/or analysed during the current study are not publicly available due [personal data protection law]

553 but are available from the corresponding author on reasonable request.

\section{Competing interest}

555 The authors declare that they have no competing interests

\section{$556 \quad$ Funding}

557 No funding sources was used for the study

\section{Authors' Contributions}

$\mathrm{KB}$ realized the creation and analysis of the system model, and was a major contributor in writing the manuscript. IK realized the creation and analysis of the system model. All authors read and approved the final manuscript.

\section{References}

563 Ahmad Fudholi, Kamaruzzaman Sopian, Mohammad H. Yazdi, Mohd Hafidz Ruslan, Adnan Ibrahim, Hussein A. Kazem.

564 Performance analysis of photovoltaic thermal (PVT) water collectors. Energy Conversion and Management 78 (2014) 641-651

Alba Ramos, Maria Anna Chatzopoulou, Ilaria Guarracino, James Freeman, Christos N. Markides. Hybrid photovoltaicthermal solar systems for combined heating, cooling and power provision in the urban environment. Energy Conversion and Management 150 (2017) 838-850.

Alzaabi AA, Badawiyeh NK, Hantoush HO, Hamid AK. Electrical/thermal performance of hybrid PV/T system in Sharjah, UAE. International. J Smart Grid Clean Energy 2014;3:385-9.

581 Bergene T, Løvvik OM. Model calculations on a flat-plate solar heat collector with integrated solar cells. Sol Energy

Augusto Bianchini, Alessandro Guzzini, Marco Pellegrini, Cesare Saccani. Photovoltaic/thermal (PV/T) solar system: Experimental measurements, performance analysis and economic assessment. Renewable Energy 111 (2017) 543-555

Bakker M, Zondag HA, Van Helden WGJ. Design of a dual flow photovoltaic/thermal combi panel. In: PV in Europe, Rome, 2002.

Bakker M, Zondag HA, Elswijk MJ, Ottenbros MTN, Van Helden WGJ. Outdoor performance of uncovered PV/Thermal panels. In: 19th EPSEC, Paris, 2004. 
Boer KW, Tamm G. Solar conversion under consideration of energy and entropy. Solar Energy 2003;74:525-8.

Boer KW, Tamm G. Solar conversion under consideration of energy and entropy. Solar Energy 2003; 74:525-8.

Buker MS, Mempouo B, Riffat SB. Performance evaluation and techno-economic analysis of a novel building integrated PV/T roof collector: an experimental validation. Energy and Buildings 2014;76:164-75.

Coventry, J.S., Lovegrove, K., 2003. Development of an approach to compare the 'value' of electrical and thermal output from a domestic Pv/thermal system. Review of 218th ref on Riffat and Saffa (2011). Solar Energy 75, 63-72.

Cox CH, Raghuraman P. Design considerations for flat-plate photovoltaic/thermal collectors. Solar Energy 1985;35(3):227-41.

Daghigh R, Ibrahim A, Jina GL, Ruslan MH, Sopian K. Predicting the performance of amorphous and crystalline silicon based PV solar thermal collectors. Energy Convers Manag 2011;52(3):1741-7.

Farghally H.M., Ahmed N.M., El-madany N.M., Atia D.M., Fahmy F.H., "Design and Sensitivity Analysis of 599 600 Photovoltaic/Thermal Solar Collector", International Energy Journal, 15: 21-32, (2015)

Florschuetz LW. Extension of the Hottel-Whillier model to the analysis of combined photovoltaic/thermal flat plate collectors. Solar Energy 1979;22:361-6.

Fujisawa T, Tani T. Binary utilization of solar energy with photovoltaic-thermal hybrid collector. In: ISES Solar World Congress, Korea, 1997.

Garg HP, Agarwal RK. Some aspects of a PV/T collector/forced circulation flat plate solar water haeter with solar cells. Energy Convers Manage 1995;36(2):87-99.

Gu, Y., Zhang, X., Myhren, J.A., Han, M., Chen, X., Yuan, Y., Techno-economic analysis of a solar photovoltaic/thermal (PV/T) concentrator for building application in Sweden using Monte Carlo method. Energy Conversion and Management Volume 165, 1 June 2018, Pages 8-24.

Hausler T, Rogass H. Latent heat storage on photovoltaics. In: 16th EPSEC, Glasgow, 2000.

Hayakashi B, Muzusaki K, Satoh T, Hatanaka T. Research and development of photovoltaic/thermal hybrid solar power generation system. In: ISES Solar World Congress, Kobe, 1989.

Heimrath, R., Haller, M., 2007. Advanced storage concepts for solar and low energy buildings, A Report of IEA Solar Heating and Cooling Programme. Task 32 Report A2 of Subtask A.

Herrando M, Markides CN, Hellgardt K, et al. A UK-based assessment of hybrid PV and solar-thermal systems for domestic heating and power: System performance. Applied Energy 2014;122:288-309. 
625 Heyd, G.T., The Probabilistic Evaluation of Net Present Value of Electric Power Distribution Systems Based on the Kaldor-

626

627

628

629

630

631

632

633

634

635

636

637

638

639

640

641

642

643

644

645

646

647

648

649

650

651

652

653

654

655

656

657

658

659

660

661

662

663

664

665

Hicks Compensation Principle. IEEE Transactions on Power Systems, VOL. 33, NO. 4, JULY 2018.

Huang BJ, Lin TH, Hung WC, Sun FS. Solar photo-voltaic/thermal co-generation collector. In: ISES Solar World Congress, Jerusalem, 1999.

Huang BJ, Lin TH, Hung WC, Sun FS. Performance evaluation of solar photovoltaic/thermal systems. Solar Energy 2001;70(5):443-8.

Ibrahim A, Fudholi A, Sopian K, Othman MY, Ruslan MH. Efficiencies and improvement potential of building integrated PV thermal (BIPVT) system. Energy Conversion and Management 2014;77:527-34.

Imteaz, M.A., Ahsan, A. Solar panels: Real efficiencies, potential productions and payback periods for major Australian cities. Sustainable Energy Technologies and Assessments Volume 25, February 2018, Pages 119-125.

Ito S, Miura N, Wang K. Performance of a heat pump using direct expansion solar collectors. Solar Energy 1999;65(3):189-96.

Jacovides, C.P., Tymvios, F.S., Assimakopoulos, V.D., Kaltsounides, N.A.: 'Comparative study of various correlations in estimating hourly diffuse fraction of global solar radiation’, Renewable Energy, 2016, 31, pp. 2492-2504

Jai Prakash Transient analysis of a photovoltaic-thermal solar collector for co-generation of electricity and hot air/water. Energy Conversion and Management Volume 35, Issue 11, November 1994, Pages 967-972.

JieJia Jun Han, Tin-tai Chow, HuaYi, Jianping Lu, WeiHe, Wei Sun. Effect of fluid flow and packing factor on energy performance of a wall-mounted hybrid photovoltaic/water-heating collector system. Energy and Buildings Volume 38, Issue 12, December 2006, Pages 1380-1387.

Jin-Hee Kim Jun-Tae Kim. Comparison of Electrical and Thermal Performances of Glazed and Unglazed PVT Collectors. International Journal of Photoenergy, Volume 2012, 7 pages.

Ka-Kui Tse, Tin-Tai Chowa, Yan Su. Performance evaluation and economic analysis of a full scalewater-based photovoltaic/thermal (PV/T) system in an office building. Energy and Buildings 122 (2016) 42-52

Kalogirou SA. Use of TRNSYS for modelling and simulation of a hybrid PV-thermal solar system for Cyprus. Renewable Energy 2001;23:247-60.

Kalogirou, S.A., Tripanagnostopoulos, Y., Hybrid PV/T solar systems for domestic hot water and electricity production. Energy Conversion and Management 7 (2006) 3368-3382

Kalogirou, S.A., Tripanagnostopoulos, Y., 2007. Industrial application of PVT solar energy systems. Appl. Therm. Eng. 27 (89), 1259-1270. 
666

667 668

669 670

671

672

673

674

675

676

677

678

679

680

681

682

683

684

685

686

687

688

689

690

691

692

693

694

695

696

697

698

699

700

701

702

703

704

705

706

707

Karl H. Photovoltaischer Hybridkollektor. In: Fourth international congress laser, 79 opto-electronics, Munchen, 1979.

Kiran S, Devadiga U. Performance analysis of hybrid PV/Thermal systems. Int J Emerg Technol Adv Eng 2014;4(3):80-6.

Komp RJ. Field experience and performance evaluation of a novel photovoltaic-thermal hybrid solar energy collector. Intersol 1985;85.

Krauter S, Araujo G, Schroer S, Hanitsch R, Salhi MJ, Triebel C, et al. Combined photovoltaic and solar thermal systems for fac-ade integration and building insulation. Solar Energy 1999;67(4-6):239-48.

Krauter S, Salhi MJ, Schroer S, Hanitsch R. New fac-ade system consisting of combined photovoltaic and solar thermal generators with building insulation. In: Seventh IBPSA, Rio de Janeiro, Brazil, 2001.

Lalovic B, Kiss Z, Weakliem H. A hybrid amorphous silicon photovoltaic and thermal solar collector. Solar Cells $1986 ; 19: 131-8$.

Lalovic B, Pavlovic T, Kiss Z, van Dine J. The application of hybrid a-Si:H PV and thermal collectors for different usages. In: Eighth EPSEC, 1988.

Lawrence, A., Karlsson, M., Nehler, T., Thollander, P. Effects of monetary investment, payback time and firm characteristics on electricity saving in energy-intensive industry. Applied Energy Volume 240, 15 April 2019, Pages 499-512.

Leenders F, Schaap AB, Ree BCG, van der Helden, WGJ van. Technology review on PV/Thermal concepts. In: 16th EPSEC, Glasgow, 2000.

Mahmut Sami Buker, Blaise Mempouo, Saffa B. Riffat. Performance evaluation and techno-economic analysis of a novelbuilding integrated PV/T roof collector: An experimental validation. Energy and Buildings 76 (2014) 164-175.

Marchioni, A., Magni, C.A., Investment decisions and sensitivity analysis: NPV-consistency of rates of return. European Journal of Operational Research Volume 268, Issue 1, 1 July 2018, Pages 361-372

María Herrando, Christos N. Markides. Hybrid PV and solar-thermal systems for domestic heat and power provision in the UK: Techno-economic considerations. Applied Energy 161 (2016) 512-532

Meir MG, Rekstad JB, Løvvik OM. A study of a polymer-based radiative cooling system. Solar Energy 2002;73(6):403-17.

Michael JJ, Selvarasan I. Economic analysis and environmental impact of flat plate roof mounted solar energy systems. Solar Energy 2017;142:159-70.

Mishra, R.K., Tiwari, G.N., 2013. Energy matrices analyses of hybrid photovoltaic thermal (HPVT) water collector with different PV technology. Solar Energy 91, 161-173. 
708

709

710

711

712

713

714

715

716

717

718

719

720

721

722

723 724

725

726

727

728

729

730

731

732

733

734

735

736

737

738

739

740

Minglu Qu, Jianbo Chen, Linjie Nie, Fengshu Li, Qian Yu, TanWang. Experimental study on the operating characteristics of a novel photovoltaic/thermal integrated dual-source heat pump water heating system. Applied Thermal Engineering 94 (2016) $819-82$.

Niccolo`Aste, Fabrizio Leonforte, Claudio Del Pero. Design, modeling and performance monitoring of a photovoltaic-thermal (PVT) water collector. Solar Energy 112 (2015) 85-99

Niccolò Aste, Claudio Del Pero, Fabrizio Leonforte, Massimiliano Manfren. Performance monitoring and modeling of an uncovered photovoltaic-thermal (PVT) water collector. Solar Energy 135 (2016) 551-568.

Rasoul, S. A., Nikoofard, S., Ugursal, V.I., Morrison, I.B., Techno-economic assessment of photovoltaic (PV) and building integrated photovoltaic/thermal (BIPV/T) system retrofits in the Canadian housing stock. Energy and Buildings, 152 (2017), pp. 667-679

Reindl, D.T., Beckman, W.A., Duffie, J.A., 'Diffuse fraction correlations', Solar Energy, 1990, 45, pp. 1-7

Riggs BC, Biedenharnb R, Dougher C, et al. Techno-economic analysis of hybrid PV/T systems for process heat using electricity to subsidize the cost of heat. Applied Energy 2017;208:1370-8.

Rockendorf G, Sillmann R, Podlowski L, Litzenburger B. PV-hybrid and thermo-electric collectors. Solar Energy 1999;67(46):227-37.

Rosa-Clot M, Rosa-Clot P, Tina GM, Ventura C. Experimental PV-thermal power plants based on TESPI panel. Solar Energy 2016;133:305-14.

Saitoh H, Hamada Y, Kubota H, Nakamura M, Ochifuji K, Yokoyama S, et al. Field experiments and analyses on a hybrid solar collector. Applied Thermal Engineering 2003;23(16):2089-105.

Sandnes B, Rekstad J. A photovoltaic/thermal (PV/T) collector with a polymer absorber plate. Experimental study and analytical model. Solar Energy 2002;72(1):63-73.

Scharmer, K., Greif, J., 'European Solar Radiation Atlas, Vol. 1, Fundamentals and Maps', Published for the Commission of the European Communities by Presses de l'Ecole, Ecole des Mines de Paris, France, 2000.

Schwartz R, Rao KHS, Tscharner R. Computer-aided analysis of thermal images of solar cells and solar PV/T collectors. In: Fifth EPSEC, Athens, 1983.

Soerensen B. Modelling of hybrid PV-thermal systems. In: 17th EPSEC, Munich, 2001.

Suzuki A, Kitamura S. Combined photovoltaic and thermal hybrid collector. Japan J Phys 1979;19(2): $79-83$. 
Tcmb,http://www.tcmb.gov.tr/wps/wcm/connect/TR/TCMB+TR/Main+Menu/Istatistikler/Enflasyon+Verileri/Tuketici+Fiyatl ari. Accessed 14 December 2020.

Thomas HP, Hayter SJ, Martin RL, Pierce LK. PV and PV/hybrid products for buildings. In: 16th EPSEC, Glasgow, 2000.

Tripanagnostopoulos Y, Nousia Th, Souliotis M, Yianoulis P. Hybrid photovoltaic/thermal solar systems. Solar Energy 2002;72(3):217-34.

Tripanagnostopoulos, Y., Souliotis, M., Battisti, R., Corrado, A., 2005. Energy, cost and LCA results of PV and hybrid PVT 759 solar systems. Progress Photovoltaics 13 (3), 235-250.

Tselepis S, Tripanagnostopoulos Y. Economic analysis of hybrid photovoltaic/thermal solar systems and comparison with standard PV modules. In: PV in Europe, Rome, 2002.

Wilson R, Young A. The embodied energy PP of photovoltaic installations applied to buildings in the UK. Building and Environment 1996;31(4):299-305.

Wolf M. Performance analysis of combined heating and photovoltaic power systems for residences. Energy Conversation 1976;16:79-90.

Yazdanifard F, Ebrahimnia-Bajestan E, Ameri M. Investigating the performance of a water-based PV/thermal (PV/T) collector in laminar and turbulent flow regime. Renewable Energy 2016;99:295-306.

Zhang X, Shen J, Adkins D, et al. The early design stage for building renovation with a novel loop-heat-pipe based solar thermal facade (LHP-STF) heat pump water heating system: Techno-economic analysis in three European climates. Energy Convers Manage 2015;106:964-86.

Žižlavský, O., Net present value approach: method for economic assessment of innovation projects. 19th International Scientific Conference; Economics and Management 2014, ICEM 2014, $23-25$ April 2014, Riga, Latvia

Zondag HA, De Vries DW, Van Helden WGJ, Van Zolingen RJC, Van Steenhoven AA. The yield of different combined PVthermal collector designs. Solar Energy 2003;74:253-69. 
Figures

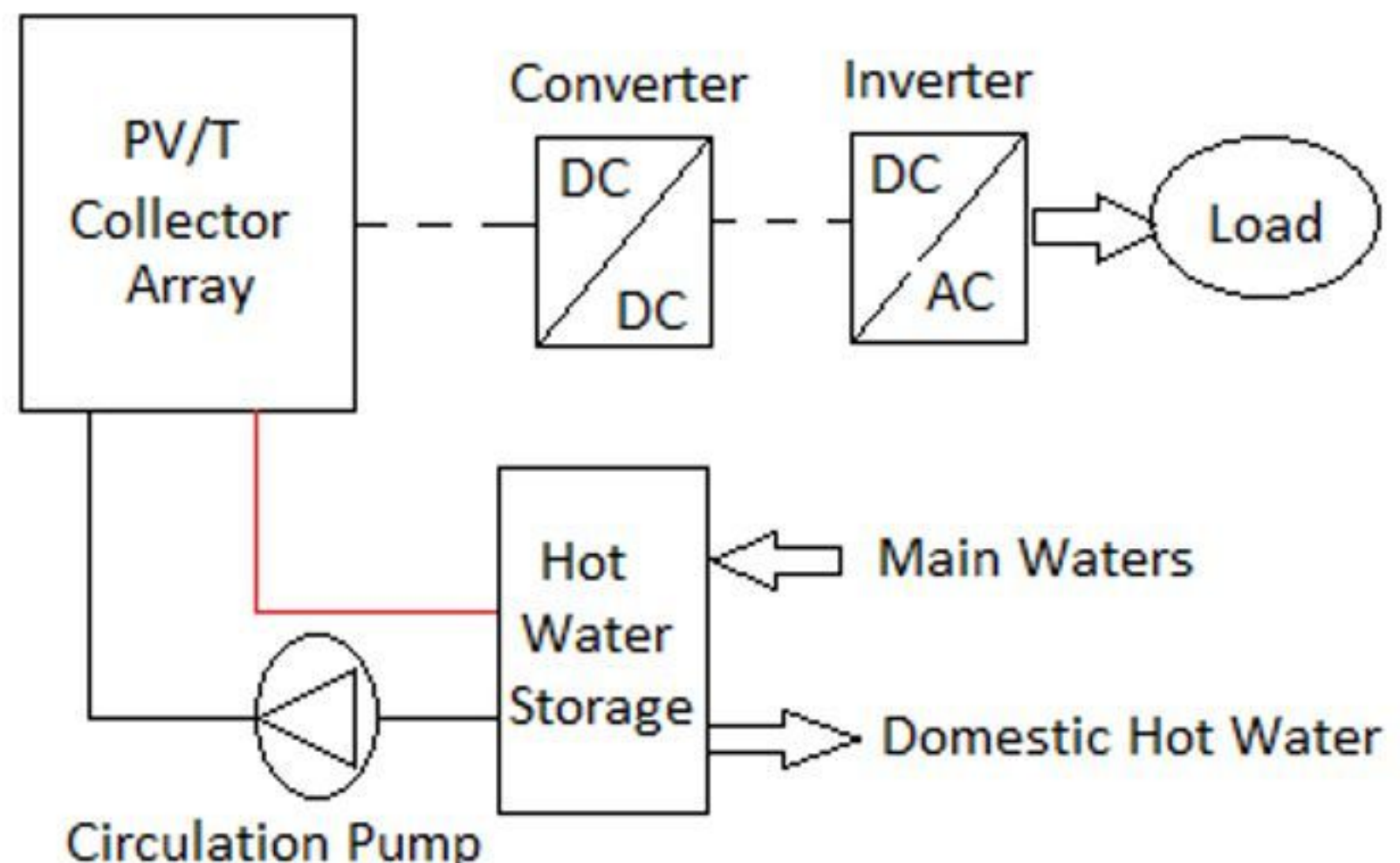

Figure 1

Block Diagram of the PV/T System

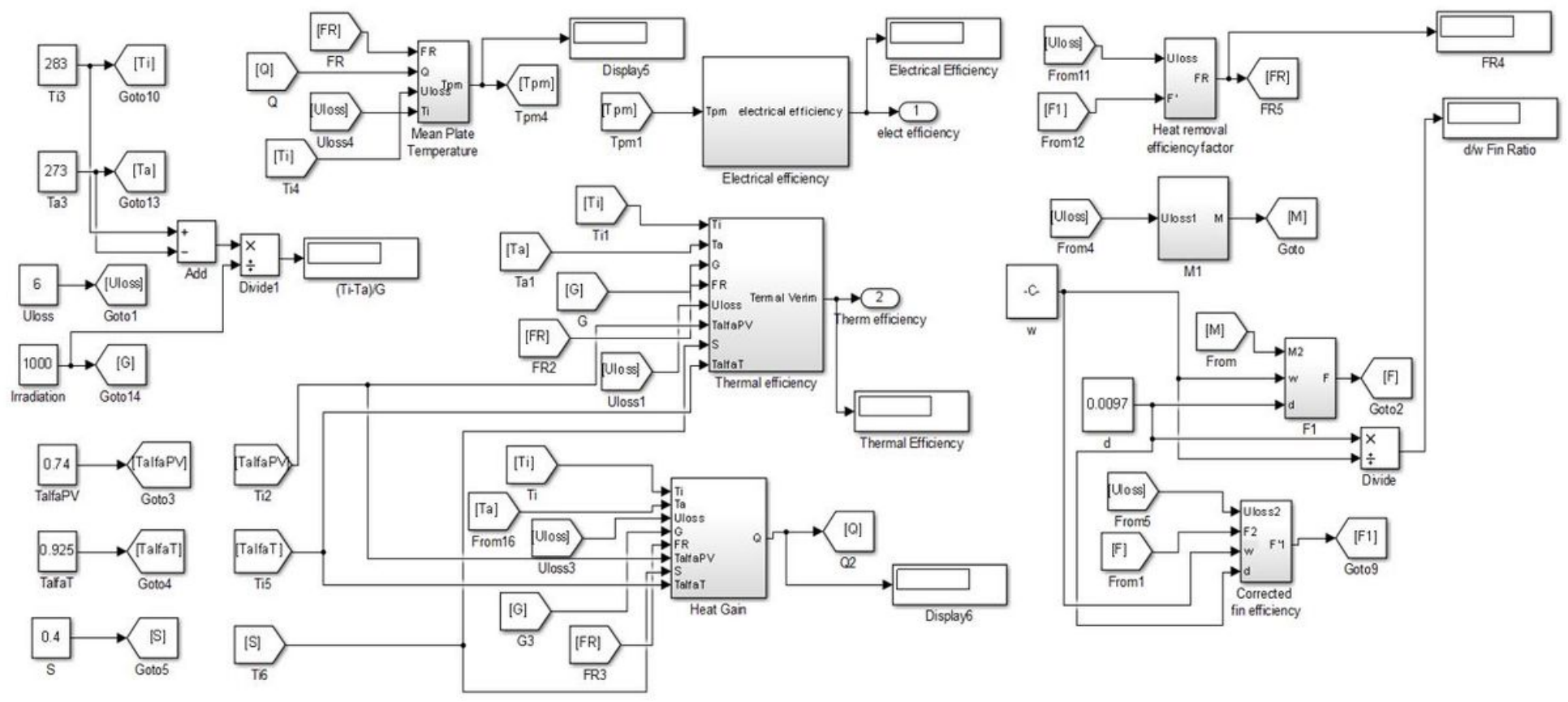


Figure 2

MATLAB/Simulink Model of the PV/T Collector
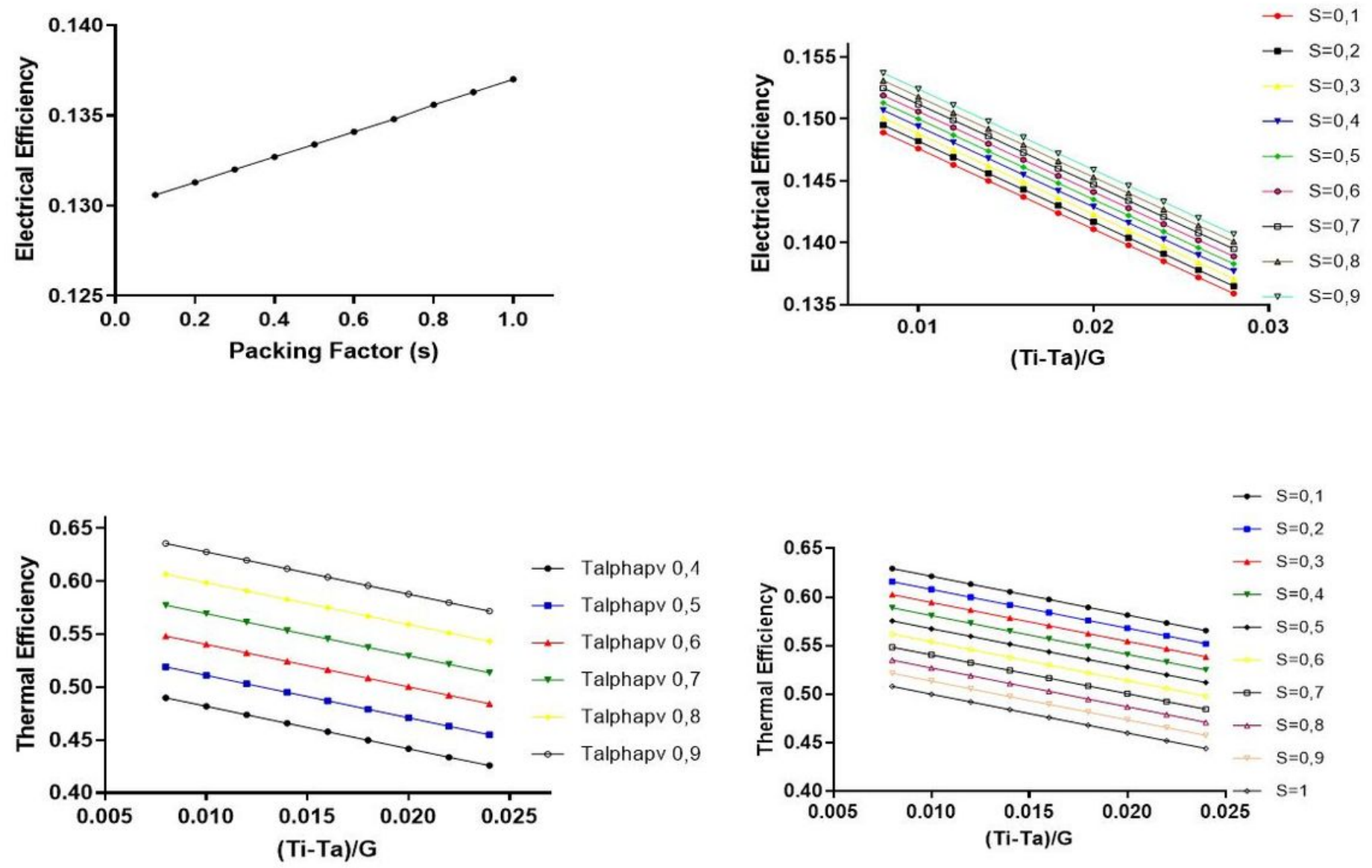

Figure 3

The effect of the s and tapv on the performance of the electrical and thermal efficiency 


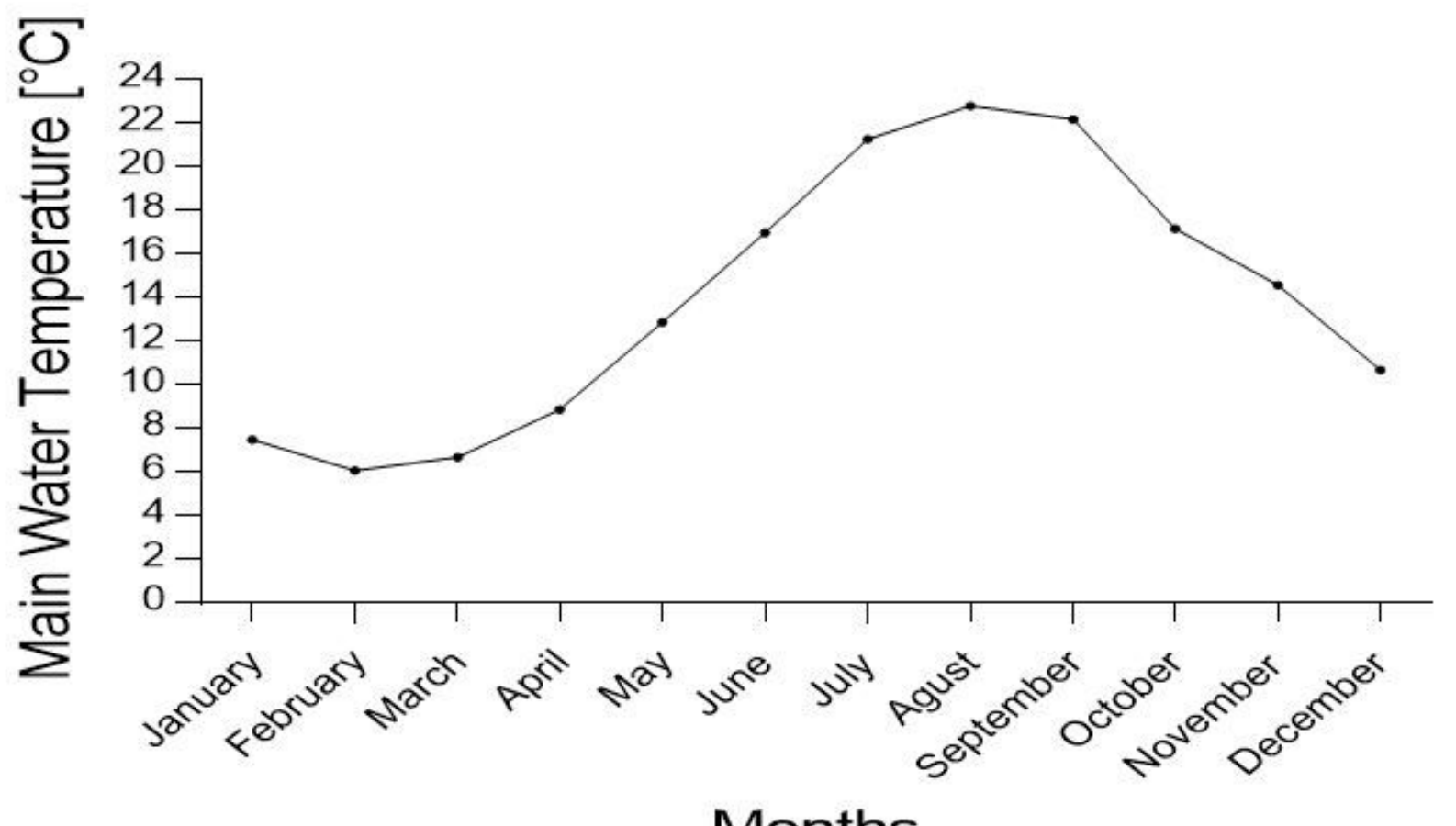

Months

Figure 4

Mains Water Temperature
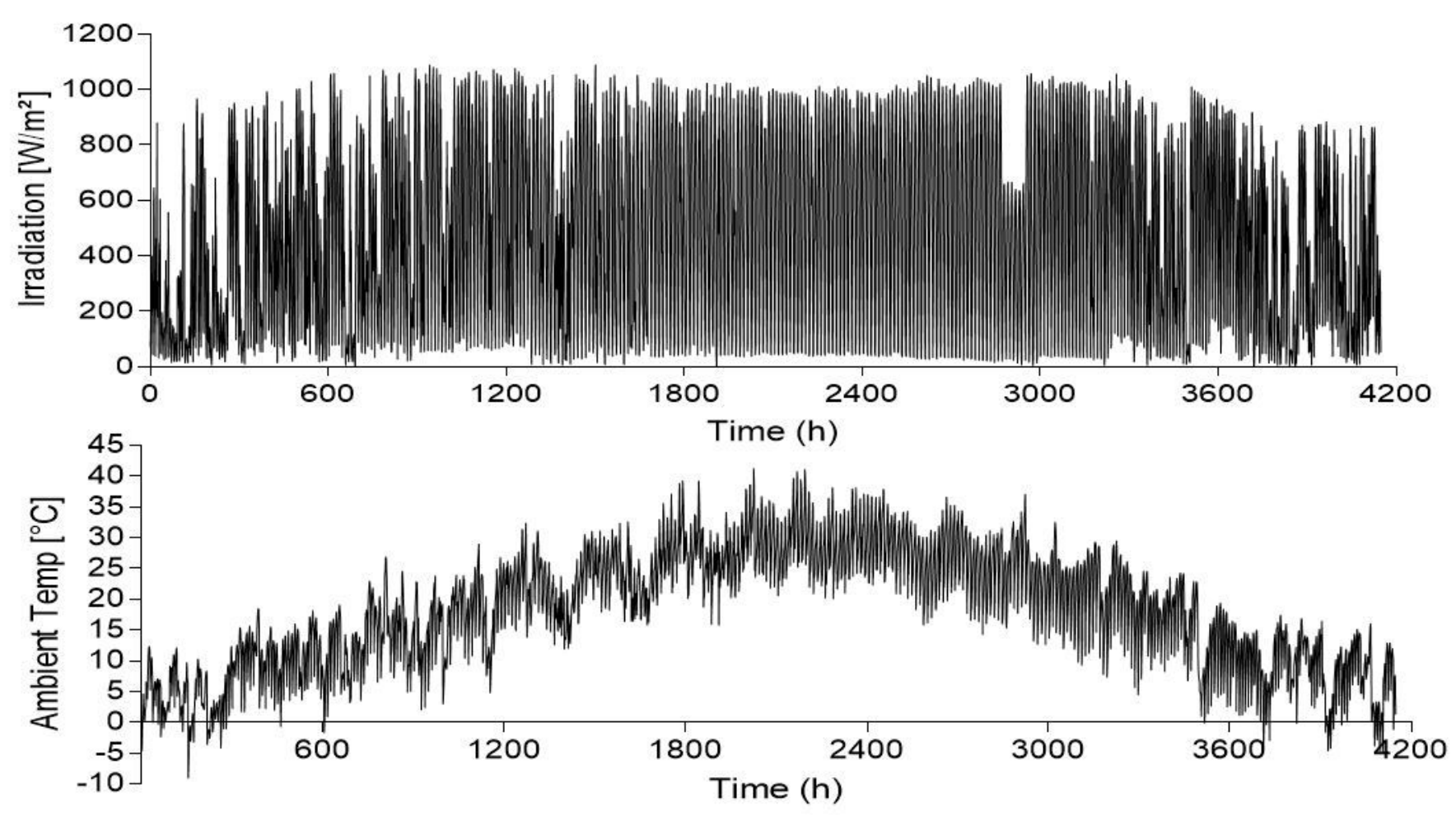

Figure 5 
Hourly average irradiation and ambient temperature

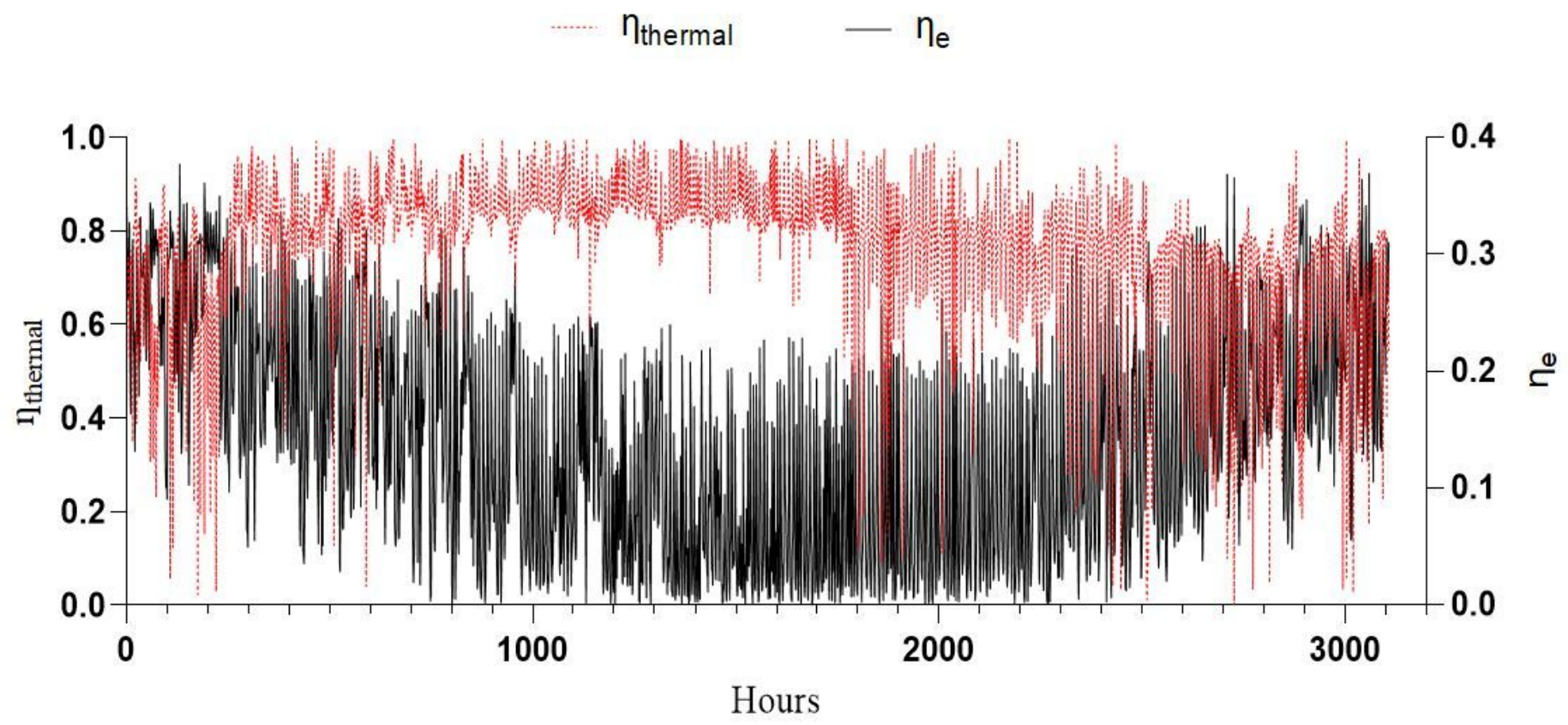

Figure 6

Thermal and electrical efficiency of the PV/T collector 

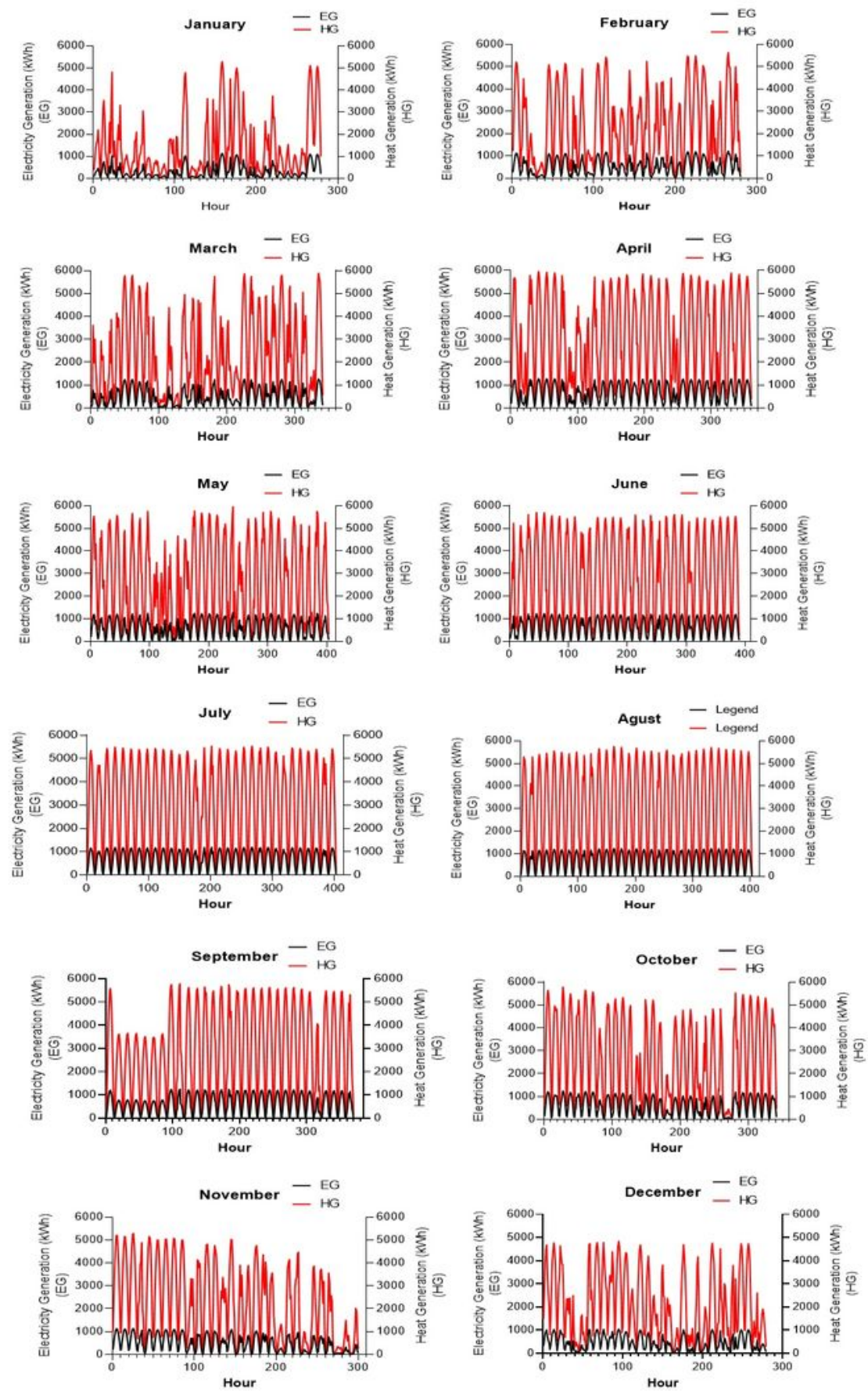

Figure 7

Monthly Electricity and Heat Generation 